Effect of m-learning on students' academic performance mediated by facilitation discourse and flexibility
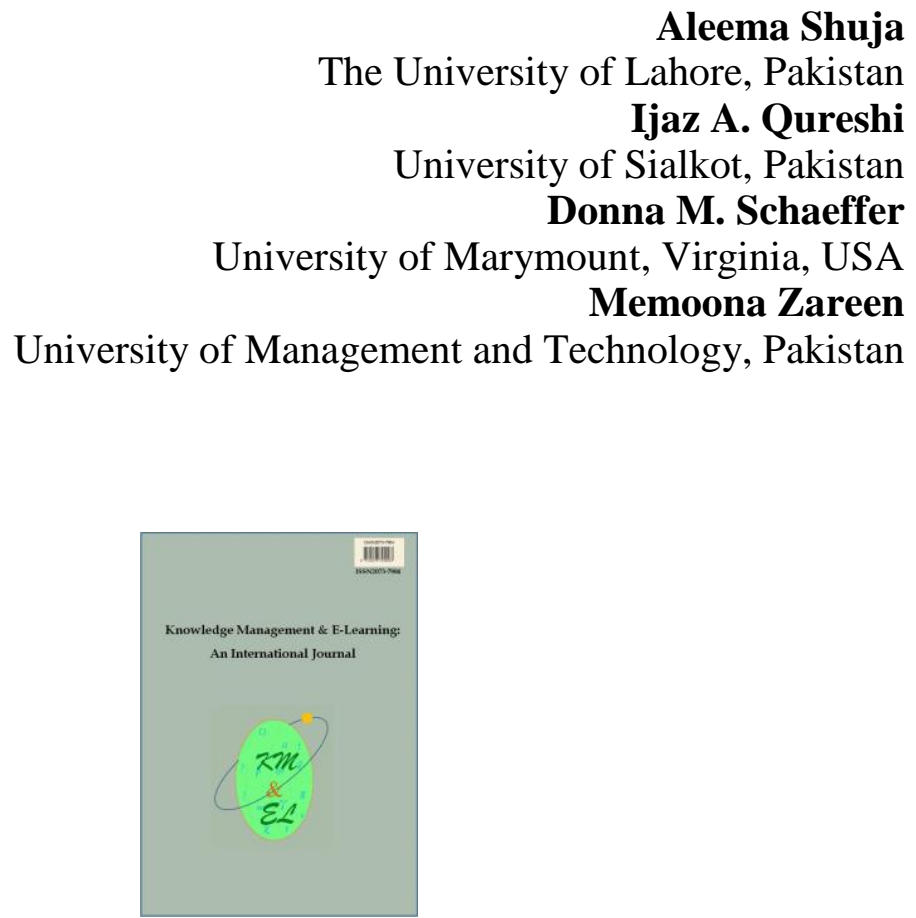

Knowledge Management \& E-Learning: An International Journal (KM\&EL) ISSN 2073-7904

Recommended citation:

Shuja, A., Qureshi, I. A., Schaeffer, D. M., \& Zareen, M. (2019). Effect of m-learning on students' academic performance mediated by facilitation discourse and flexibility. Knowledge Management \& E-Learning, 11(2), 158-200. https://doi.org/10.34105/j.kmel.2019.11.009 


\title{
Effect of m-learning on students' academic performance mediated by facilitation discourse and flexibility
}

\author{
Aleema Shuja* \\ Lahore Business School \\ The University of Lahore, Pakistan \\ E-mail: Aleema.shuja@lbs.uol.edu.pk
}

\section{Ijaz A. Qureshi}

Vice Chancellor

University of Sialkot, Pakistan

E-mail: vc@uskt.edu.pk

\section{Donna M. Schaeffer}

Business and Information Systems

University of Marymount, Virginia, USA

E-mail: donna_schaeffer@hotmail.com

\section{Memoona Zareen}

Secretary, Association of Management Development Institutions in Pakistan (AMDIP)

University of Management and Technology, Pakistan

E-mail: memoona.zareen@umt.edu.pk

*Corresponding author

\begin{abstract}
Conventional classroom instruction had already been transformed in to electronic mode of teaching and learning. Use of mobile technology is evolving in global and local context, as in Pakistan. Gaining insights from Media Richness Theory, the study intends to examine how m-learning pedagogy, opens up avenues for students' learning and enhances their educational performance, endorsed by facilitation discourse and flexibility. In this cross-sectional study, data was collected from students in Private Universities in Lahore Pakistan. Drawing results from structural equation modelling, findings revealed that use of mobile devices is on great demand for providing flexible and discussion-oriented learning to students and lifts up their academic output. Facilitation discourse and flexibility play a robust intervening role in producing pronounced impact of m-learning on learners' effectiveness.
\end{abstract}

Keywords: Mobile-learning; Facilitation discourse; Flexibility; Students academic performance; Media richness theory

Biographical notes: Aleema Shuja is a Permanent Lecturer in Lahore Business School (LBS) at The University of Lahore, Pakistan. She completed Masters of Science in Management Sciences MS (MS) from COMSATS Institute of 
Information Technology, Lahore. Her areas of research include M-Learning, Organizational Resilience, Change Management, Leadership and Knowledge Management. The work carried out by her in areas of responsibility and research includes: delivering lectures, seminars and tutorials; developing and implementing new methods of teaching to reflect changes in research; designing, undertaking personal research projects and actively contributing to the institution's research profile; representing the institution at professional conferences (IFKAD 2017 and 2018) and seminars, and contributing to these as necessary. More details can be found out from faculty profile on official website of The University of Lahore, can be accessed at: https://faculty.uol.edu.pk/Faculty/7947/Aleema\%20Shuja

Prof. Dr. Ijaz A. Qureshi is the Vice Chancellor in University of Sialkot, Pakistan. He obtained his Doctorate in MIS from Argosy University USA in 2006. He has been member of Academy of Management since 2015 and member of IEEE since 2014. Ijaz enjoys his participation in the innovative academic activities in Pakistan and abroad. $\mathrm{He}$ is in the Editorial Board of Journal of Knowledge Management and E-Learning and in the Editorial Board of IISTE. His research is primarily focused on M-Learning, E-Learning that enables students in the developing nations to benefit from the technology to get state of the art learning opportunities in their own environment. Ijaz has used M-Learning technologies to invite foreign guests in his classes in Pakistan and he regularly delivers lectures abroad.

Prof. Dr. Donna Schaeffer is the Professor of Business and Information Systems in University of Marymount, Virginia, USA. She has taught technology, leadership, and ethics courses at universities in the United States, Germany, and Korea. Over the course of her academic career, she has received outstanding teaching awards three times and has published more than 50 articles and book chapters.

Memoona Zareen is the Secretary of Association of Management Development Institutions in Pakistan (AMDIP) at University of Management and Technology, Lahore, Pakistan. She did her MPhil Business Administration from Superior University, Lahore Pakistan in 2013 and in 2010 completed Master of Business and IT from Punjab University Lahore.

\section{Introduction}

Education and learning are thought to be most crucial foundations of a growing economy, yet the academic system needs radical transformations and major technological reforms. Mobile learning, a more pronounced form of e-learning, is emerging as a stepping stone towards bringing revolution to the educational sector and providing hands on solutions to the pertaining problems (West, 2013). In contemporary education management, students tend to greatly rely upon mobile technologies to achieve dramatic performance outcomes. With intense inclination towards cellular connectivity, mobile technology is playing critical role in improving learning of the students as well as instructors. Digitized technology has put way forward to enable access to information and delivery of latest learning content regardless of student's availability (Jacobs, 2013). One of the remarkable consequences of m-learning is that it engages, empowers and supports learning in such a manner that radically transforms knowledge seeking mechanism for students (West, 2012). 
After the advent of internet technology, the next technological revolution was development of wireless mobiles, smartphones, tablets and handhelds that are ubiquitous, reasonable, and flexible (Higgins, Xiao, \& Katsipataki, 2012). Mobile technology has been widely accepted by students not merely for social networking but also for the sake of making education more customized as per their learning needs. The reason for quick acceptance of learning through mobile devices is that wireless media rich practices endure higher engagement and collaboration among instructors and students. Students become proficient in harnessing internet and mobile platforms for educational purposes and boosting learning (Lai, Chang, Li, Fan, \& Wu, 2013). The rising trend of adopting mobile phones for learning purposes can be observed in developing nations such as Pakistan. According to statistics provided by Pakistan Telecommunication Authority (PTA, 2017), by the end of April 2017 a total of 40.56mn subscribers were reported to use internet for communication and knowledge acquisition. Thus, the number sets a new record of internet users. A total of 976,600 subscriptions had been reported till the mid of 2017, which reveal a sharp rise in mobile broadband subscription (PTA, 2017). Furthermore, more than $42 \mathrm{bn}$ subscribers use $3 \mathrm{G}$ and $4 \mathrm{G}$ technology for internet browsing (Zeb, 2017). It has been accounted that almost $77 \%$ people in Pakistan within age group of 21-30 years are smartphone users, whereas, 12\% fall between 31-40 years. In "Mobile Economy 2017-Asia Pacific", a report developed by GSMA, there is sharp inclination towards usage of mobile technologies for social interactions and information acquisition. PTA estimated that population of $139 \mathrm{mn}$ smartphone users will rise up to $156 \mathrm{mn}$ in 2020, having an acute rise of $17 \mathrm{mn}$ individuals (Kanwal, 2017). Mobiles have provided tremendous opportunities for academia to digitize teaching pedagogy to provide maximum ease to students (Okeleke, Rogers, \& Pedros, 2017). Countries, comprised of collectivistic culture with higher social influence, such as Turkey, exhibit higher extent of inclination to adopt mobile technology for learning purpose than that of nations with individualistic culture such as Canada (Arpaci, 2015). Hence, Pakistan is a state where an increasing trend for mobile technology can be observed particularly for the purpose of seeking knowledge.

In previous years, cell phones had been majorly used for purpose of communication, now the trend has shifted towards using them for gaining and sharing information. People are utilizing technology as means of fundamental didactic channel in academic establishments (El-Hussein \& Cronje, 2010). Furthermore, the count of users for this purpose is consistently rising, this can be judged through the given statistics. It has become remarkably convenient for students and teachers to beat the problems of leaning and instructing at any time and place. It would not be overestimating to say that usage of mobiles has been extensively embraced by students and teachers due to its working, standards and philosophy (Huang \& Hsieh, 2012).

Technology has been deeply rooted in education for more than two decades, however, technological revolution through portable gadgets such as mobile phones has brought changes radically (Valk, Rashid, \& Elder, 2010). Mobile phones have changed the way students seek knowledge and develop cognition. Thus, learning through mobile technology, facilitated by access to academic resources, socializing with each within and outside the physical boundaries and sharing experiences, helps to back the learning objectives of individuals as well as institutions (Farid, Ahmad, Niaz, Arif, Shamshirband, $\&$ Khattak, 2015). Mobile technology has brought diversity in the educational pedagogies and delivered a way to become more collaboration oriented in learning practices (Wang, Shen, Novak, \& Pan, 2009). There is a shift from traditional classroom learning and teaching to an interactive blended learning that is works on the principle of delivering live broadcasts of present class room teaching via mobile gadgets (Wang et al., 2009). Sung and Mayer (2013) found out a significant positive effect on students' learning and 
performance as a result of using mobile technologies for knowledge sharing and acquisition. Students' inspiration towards using mobile technology is directly related with improved educational productivity of students in Chinese Universities. Although, some research found a negative impact of m-learning in students' achievement (Sung \& Mayer, 2013; Froese, Carpenter, Inman, Schooley, Barnes, Brecht, \& Chacon, 2012).

\subsection{Problem background}

A huge population of Pakistan is unable to experience learning through traditional schooling, which unfortunately makes quite difficult for young citizens, especially girls, to gain formal education and develop themselves (Waqar, 2014). For enormous number of mobile users, there exist hitches usually confronted by people in remote areas. Hurdles in attaining formal education are also faced by the employees or workers who do not get time to learn and increase qualification, in order to move above the career ladder. Mlearning can provide solutions to these problems and encourage people to grow intellectually and professionally (Saccol, Reinhard, Schlemmer, \& Barbosa, 2010). Within a developing scenario, countries such as Pakistan should develop a culture where students and teachers both use mobiles constructively for learning commitment. Since a decade, globally education had comprised of two modes of delivery i.e. electronic and classroom learning. E-learning enabled students to undertake education at any time, in virtual groups or isolation and discuss contents with teachers via asynchronous mechanisms, therefore, m-learning supports self-managed work frameworks and improve efficiency of learning management system (Weichhart, Stary, \& Appel, 2018). Contrary to it, class room learning demands learning at an allocated place and set time. The objective is to identify which positive factors associated with using mobile phones can improve undergraduates' academic performance (Ifeanyi \& Chukwuere, 2018). Such digitized or computer-based learning environment helps to develop problem solving skills for building proficiency of explaining complex scenarios (Yuan, Wang, Kushniruk, \& Peng, 2016). Envisaging this scenario, it is deemed important to analyze mechanism of how m-learning can boost academic performance of students while promoting teachers' role and adaptability in the process.

Rising embeddedness of mobile technology has led instructors to deeply assimilate their role in assisting students and generating innovative modes of learning for distant students. Such an instruction methodology must be extensively introduced in evolving nations. Pakistani universities severely lack mobile-assisted learning supplemented with tutors' support and discourse, thus deficient in two-way interaction (Butt \& Qaisar, 2017). Kent (2016) found out that through mobile learning students use social media platform such as Blackboard discussions and Facebook, where they post their content and stimulate discussions. These activities have substantial impact on students' self-reporting and academic outcomes. These activities have substantial impact on students' self-reporting and academic outcomes. As a result, students are unable to realize their full potential and build capacity. There remains a deficiency in content delivery even if the content is perfectly designed. Students cannot ask questions and actively participate in virtual classroom learning. The problems can be addressed by teachers playing a stimulatory role for invigorating students to gain maximum understanding of the lesson (Mazzolini \& Maddison, 2007). It has been established that cloud-based learning and teaching mechanism boost students' motivation to work smarter for improved grades (Chiu \& Li, 2015). On the other hand, instructors are reluctant in seeking and exploiting the true benefits of mobile technology that can enrich student learning. In order to improve students' educational conduct, m-learning ought to be 
blended with teachers' facilitation discourse. Faculty must play instrumental role in enabling interactivity, discussion and feedback for better content understanding for the learners (Liu, Wang, Liang, Chan, Ko, \& Yang, 2003). When students are motivated to gather knowledge through mobile devices, the role of instructor becomes critical in facilitating students to understand the learning content and foster feedback (Balaji \& Chakrabarti, 2010). Instructors need to be active in utilizing the advanced m-learning pedagogy for conveying live lecture transmission of classroom learning aided with guidance, communication and supervision for the leaners (Ratto, Shapiro, Truong, \& Griswold, 2003). Sequentially, students can effortlessly personalize resource of receiving the content, while asking queries from instructor to address them instantaneously. HEIs in Pakistan are highly deficient in exercising this phenomenon for improving quality of education and learning for students. Thus, facilitation discourse playing a mediating role in increasing the impact of m-learning on learners' performance.

M-learning provides flexibility for accessing learning content for enlightening learning accomplishment (Olasina, 2018). Mobile learning equips students with the choice to learn at their personalized place, pace and using convenient learning approach. Students in less industrialized nations do not realize the actual potential of using flexible pedagogical academic tools through m-learning (Gordon, 2014). The influence of $\mathrm{m}$ learning on students' productivity is likely to increase when flexibility intervenes as mediator (Wen, Brayshaw, \& Gordon, 2012). Portable gadgets are least used for learning purposes, even the part-timer students do not capitalize upon advantage of using cellphones for attaining flexible learning approach while working on their jobs (Wen et al., 2012). Students are still using designated classes or learning centers for gaining access to online content, yet relying on the electronic mode of learning and less exploiting mobile devices for achieving flexibility. This process hampers their ability to exercise flexibility of adaptive learning and improve their learning outcomes. M-learning lets students decide about where, what and how to learn, thus managing the bulky inflow of knowledge effectively through acquired flexibility. Consequently, they are capable of using the huge influx of information resourcefully. Moreover, flexibility in terms of portability, accessibility and assessment emerges to provide maximum comfort to the learners (Fuegen, 2012). M-learning promotes flexibility and allows access to learners to achieve just-in-time learning. Therefore, flexibility plays an intervening role in the relationship between mobile-assisted learning and students' performance. Mobile learning has dramatically changed the way knowledge had been imparted since inception of digitized or virtual learning. In prior studies, focus was laid upon analyzing the impact of $\mathrm{m}$ learning on technical proficiencies of the students, while least attention was paid to nontechnical or soft outcomes of this phenomenon (Alrasheedi \& Capretz, 2015; Andrews, Smyth, Tynan, Berriman, Vale, \& Caladine, 2011).

The study adds significance by highlighting how m-learning, through tutor's assistance and adaptation, ensures to transmit accurate information to the concerned person at the right time, thereby enhancing students' aspiration to achieve better grades in their academics (Little, 2012). There are multiple benefits of m-learning, extended not only to giving quick access to learning material but also enabling innovative thinking and problem solving in the learners (West, 2013). Students are unaware of the benefits they can accomplish by utilizing technology up to extreme potential. This is one of the reasons of declining students' performance as they spend most of their time using social media applications. Studying the role of flexibility and facilitation discourse as mediating varaibles in the relationship between m-learning and students' academic performance will provide direction to all leaners who need to gain understanding of using mobile technology for academic purpose as well. Previous researches had been grounded on analyzing the impact of M-learning on student's academic performance and implications 
on students' learning through M-learning (Sung, Chang, \& Liu, 2016), opportunities and challenges of M-learning for HEIs in Pakistan (Nawaz, 2011) and analyzing the CSFs of M-learning from teachers' perspective (Alrasheedi \& Capretz, 2015).The underlying research study intends to determine the impact of m-learning on academic performance of students in Pakistani Higher Educational Institutions (HEIs). Keeping the merits of mlearning into account, the study proposed to analyze, are students able to perform better with mobile assisted learning through mediation of facilitation discourse and flexibility? The conceptual framework has been supported by Media Richness Theory (Amaka \& Goeman, 2017; Vural, 2013). The proposed model has not been empirically tested within the context of Pakistan earlier, however, the literature studies provide insights through theoretical frameworks (Farid et al., 2015; Gordon, 2014). The results of the study will answer the research questions of does m-learning boosts the academic performance of students in Pakistan, secondly, how facilitation discourse and flexibility play mediating role by helping to lift up the positive effect of m-learning on students' educational accomplishment.

\subsection{Objectives and research questions}

The objectives of the current study are as follows

- To determine the effect of m-learning on students' academic performance in universities in Pakistan.

- To determine the influence of m-learning on student's academic performance, with facilitation discourse as mediator in developing country such as Pakistan.

- To investigate the impact of m-learning on educational performance of students, with flexibility playing mediating role in Pakistani context.

The following questions will be answered in the study

- Are students able to perform exceptional by using mobile technology for ubiquitous learning within the context of Pakistan's academic environment?

\section{Literature review}

In recent years, internet has expanded with launch of high-speed mobile internet devices (Rudd \& Rudd, 2014). Mayer and Clark (2011) highlighted five major types of online media layouts including audio, text, static graphic, video and animation, however, usage of media type vary from need or feasibility of instructor as well as learner (Plass, Moreno, \& Brünken, 2010). With rising technological trend, HEIs had also incorporated e-learning, thus pushing back the traditional form of teaching and learning (Perry \& Pilati, 2011). Since then, there appeared an integration of PC-supported instruction with media arrangements for effective learning and heightening academic performance of learners (Yang, Wang, \& Chew, 2014). Online learning is closely associated with blended learning (Moore, Dickson-Deane, \& Galyen, 2011), owe to which an increasing inclination towards m-learning has been observed. Despite of huge disposition towards using internet technology, there is still a great discrepancy between increasing technological growth and gaining learning from internet enabled devices. This gap lies in the absence of broadcasted learning; however, this gap serves a source of biggest attraction for researchers to explain the subject matter (Alrasheedi \& Capretz, 2015). 
Rockley and Cooper (2012), also suggested to investigate m-learning and its consequences on students' performance in terms of achieving educational goals.

Excitingly, students are ready to accept the notion of using mobile technology for accomplishing learning objectives as they are more comfortable in using mobile handsets. Apart from verbal cues, non-verbal communication plays active role in coordinating sender's emotions and attitudes that ultimately promote students to become more engaged in classroom discussions and give feedback (Ebrahim, Ezzadeen, \& Alhazmi, 2015). M-learning offers greater opportunity for audience to take benefit of social interactions for accomplishing highest standards of learning and academic performance (Almutairy, Davies, \& Dimitriadi, 2015). The feature of social communication in broadcasted mobile learning is useful for incapacitating the absence or clarity of verbal cues that ultimately boosts the understanding and engagement of teachers and students. Salinda Premadasa and Gayan N. Meegama (2013) investigated the dynamics of mlearning associated with use of learning management systems such as Moodle, that ensure access to campus wide and off-campus course content. By means of mobile based learning resources, the face-to-face discussion effectively takes place thus allowing for more rich understanding and improved educational productivity of students (Balaji \& Chakrabarti, 2010).

M-learning has been found to have direct positive effect on learners' academic success, however, the influence is distinct when the instructor facilitates and tracks the discussion towards main content (Wilen-Daugenti, 2009). The role of instructors is therefore, instrumental in removing the bottlenecks to students' outstanding educational learning (Alrasheedi \& Capretz, 2015). One of the best features of m-learning is access to learning material with mobility and ubiquity, promoting flexibility in terms of location, place, time, speed and space, which is quite impossible for desktop internet users (Andrews et al., 2011). M-learning involves knowledge sharing, problem solving and one-to-one discussion, thus allowing for maximum extent of feedback among both the teaching and learning ends (Keskin \& Metcalf, 2011). Students regard this form of learning as source of most "instant support" in online collaborative learning (Hamm, Saltsman, Baldridge, \& Perkins, 2013). Analyzing the usage of mobile learning for gaining prompt knowledge and its effect on academic performance of students in education industry has created remarkable interest for the researchers since previous years (Alrasheedi \& Capretz, 2015). However, the cause and effect relationship between $\mathrm{m}$-learning and students' academic performance is likely to be mediated by facilitation discourse (Balaji \& Chakrabarti, 2010) and flexibility (Fuegen, 2012).

\subsection{Theoretical basis}

The conceptual model derived from the theoretical framework involves support from "Media Richness Theory" (Balaji \& Chakrabarti, 2010), a concept developed by Daft and Lengel (1986). The model gets is sustenance from Media Richness Theory (MRT), while focusing on the notion that mobile technologies play critical role in elevating students' learning and deepen communication among the interacting individuals (Sarrab, 2015). MRT supports use of media technology for the purpose of communication, knowledge sharing and knowledge acquisition. It suggests that the extent of sharing information and interaction is positively affected by customizing medium as per student's educational needs (Daft \& Lengel, 1986). M-learning, as subset of e-learning, provides comfort in terms of mobility, flexibility and collaboration in knowledge sharing (AlHajri, AlSharhan, \& Al-Hunaiyyan, 2017). It delivers greater opportunity for student-centered learning and continuous feedback (Ebrahim et al., 2015). MRT emphasizes that mobile 
media contrast in their abilities to deliver knowledge content. Media efficiency highly depends upon features of communication channel, involving access to customized information, variety in language, instant feedback and timely communication (Vyas \& Nirban, 2014). The extent of media richness also allows to transmit broadcasted learning to students which ensures maximum understanding and clarity of content (Almutairy et al., 2015). In contrast, the lower the media richness, the more the ambiguity and poor understanding by learner.

M-learning leads to emergence of facilitation discourse which helps students to perform better than before. Encouraging learning through online devices, where instructor plays an active role in enabling learners to develop thought frameworks and promotes discourse between the two communication ends (Ifeanyi \& Chukwuere, 2018; Anderson, 2004). In similar framework, MRT also relates to guarantee emergence of flexibility through m-learning for students to obtain knowledge whenever and wherever needed, resulting into academic improvements (Lan \& Sie, 2010). Kromhout (2011) studied the outcomes of flexibility and found that employees who perform through telework are able to accomplish their goals. The cause and effect relationships are developed under the comprehensions of Media Richness Theory i.e. the greater the extent of usage of mobile technology for tailored learning, the greater will be the chances of students to compete among outstanding peers, while flexibility and facilitation discourse emerge as intervening dimensions in entire process (Menchaca \& Bekele, 2008).

\subsection{Theoretical framework}

Before explaining the associations among the variables, their definitions are given below:

\subsubsection{M-learning}

M-learning is referred as "kind of learning practice that occurs when student is not static at a prearranged location, where learning takes place when the knowledge seeker benefits from learning opportunities that are dynamically delivered by mobile gadgets or technologies (O'Malley, Vavoula, Glew, Taylor, Sharples, Lefrere, \& Waycott, 2005). It is an innovation in learning that reduces learning constraints such as time and space. It is exercised through use of handy portable gadgets including smart phones, tablets, PDAs and handheld technologies. It merely uses mobile technology for providing knowledge (Gupta \& Koo, 2012). It is characterized by use of cordless gadgets to obtain learning material at any place and time.

\subsubsection{Facilitation discourse}

Facilitation discourse is defined as "process where instructors actively participate and engage students in programmed or unplanned discussion based on learning processes (Leko, Kiely, Brownell, Osipova, Dingle, \& Mundy, 2015). They assist students in solving problems and finding their solutions under instructors' guidance. Teachers play supportive and focused role in offering logical resolutions to problems (Shaffer, 2006). It is a process in which teachers are actively involved in online discussions which they deem vital for retaining learners' motivation and interest in broadcasted lectures or conventional class rooms (Balaji \& Chakrabarti, 2010). 


\subsubsection{Flexibility}

Mobile learning offers opportunity for distance learning by creating modes of effective communication among distant students and instructors (Yousuf, 2007). This enrichment in communication is an outcome of increased flexibility characterized as "convenience provided to m-learners to access learning material that is not easily available for teaching as well as learning”. M-learning yields flexibility for students to seek education anytime and anywhere, even while the learner is in non-static position. Flexibility gives interacting technology to offer autonomy to learners to be located at any place and time that is most suitable to learners (Wen et al., 2012).

\subsubsection{Students' academic performance}

A multifaceted phenomenon, influenced by diverse factors such as meta-reflective learning and cognition, interest, motivation for learning, skills, engagement, quality of teaching and socio-economic status, characterized by enhance student's capability to perform at the desired level (Lewin \& Mawoyo, 2014; Moseki \& Schulze, 2010). Tinto (1987) defined students' academic performance as a longitudinal process that involves exchanges between students' characteristics such as resources, intentions, temperaments and commitments as well as characteristics of the academic institution. Academic performance is increased by positive students' experiences that alter their commitments and intentions to positive encounters.

\subsubsection{M-learning and students' academic performance}

Technological advancements have made break through innovations in current era and huge differences in human lives. Variations in the technological advancement are consistent and will be continued in the future. Such progressions have made mark in every sector such as government, services, banking, medicine and even education management. Guspatni (2018) reported that students developed positive learning perceptions regarding the use of social applications that deliver synchronous discussion platform. Hi-tech practices in academia have created dynamic impact on learning capability and effectiveness of students. Decades before, the integration of education and technology led to emergence of e-learning, of which m-learning is a more pronounced form (Alioon \& Delialioglu, 2015). The thought of m-learning has already been rooted deeply in academic sector and has remarkably improved educational competence of students, especially those who opt to obtain distance learning (Jin, Zhang, \& Luo, 2017; Ahmed \& Parsons, 2013). Distant learners or those who used to acquire knowledge through virtual education are now able to get access to personalized learning through portable, ubiquitous and flexible sources. This eventually develops students to have effective understanding just as attained through conventional class room environment (Miller \& Cuevas, 2017; Alioon \& Delialioglu, 2015).

M-learning as an innovative instructional pedagogy plays critical role in assisting students to become efficacious in developing complex mental frameworks and understand the content accurately (Males, Bate, \& Macnish, 2017; Ng \& Nicholas, 2013). Thomas and Orthober (2011) and Huang, Lin, and Cheng (2010) established positive association between suitable use of mobile technology and leaners' configuration headed to learning along with educational achievements. Students tend to score high who incorporate mobile devices for learning than those who acquire knowledge through traditional text books (Wilkinson \& Barter, 2016). In a longitudinal study conducted on students in Taiwan, a contrast of mobile and conventional learning was established. 
Comparing pre-test grades with post-test scores, improved lexicon and academic results were recorded from students who gained education using mobile technology. Students' perceive video-based instructional methods very effective for building their selfconfidence, retained learning and homogenous understanding (Guspatni, 2018). Navaridas, Santiago, and Tourón (2013) concluded positive instructors' perception of learners' education performance and usage of flexible mobile technology in the orthodox class-room learning. Majority teachers firmly believed that mobile learning greatly influence the learning capabilities, language skills and outcomes of students (Cho, Lee, Joo, \& Becker, 2018). Young students, as active learners, use cell-phones for socializing, communicating and scholastic purposes, which create ease and interest for them to learn innovatively (Elfeky \& Masadeh, 2016; Owino, 2013). Current is an era of intense usage of mobile technology by allied health sciences students as they also capitalize upon this by sharpening their metacognitive abilities and heading to academic success (Khan, Siddiqui, Mohsin, Al Momani, \& Mirza, 2017; Dos, 2014). They develop the strength to self-regulate their learning behaviors and attitudes, which ultimately help to engage more in studies (Idir \& Iskounen, 2018) and perform best academically (Zare Bidaki, Naderi, \& Ayati, 2013). In a study conducted in Saudia, it was found that female students become active learners being deeply involved emotionally, intellectually and behaviorally in knowledge seeking tasks as compared to males (Basri, Alandejani, \& Almadani, 2018).

Ismail, Mahmood, and Abdelmaboud (2018) and Sampson and Zervas (2013) resolved that improved students' learning and performance occur due to greater interaction and blended instruction methodology. Moreover, mobile devices act as Learning Object Repositories (LORs) that provide vast sharing of knowledge assets among educational peers (Sampson \& Zervas, 2013). Mobile devices serve as cutting edge technology that provide prospects for the students to get exposure to mean time broadcast lectures and personalize channel and time of receiving the lecture content (Shonola, Joy, Oyelere, \& Suhonen, 2016). One of the best features of m-learning process is that higher degree of interaction allows students to ask questions, give feedback and sort out problems that are facilitated by the instructor (Korucu \& Alkan, 2011). All these factors advance learning and consequently performance of the students (Rabiu, Muhammed, Umaru, \& Ahmed, 2016). Additionally, apart from encouraging innovating thinking via using information technology, m-learning assists in convenient knowledge attainment for investigative learning and information sharing for collaborative learning (Roschelle, Rafanan, Bhanot, Estrella, Penuel, Nussbaum, \& Claro, 2010). Hence, mlearning provide prodigious opportunities for students to develop diverse problem solving, communication and creativity (Warschauer, Zheng, Niiya, Cotton, \& Farkas, 2014). In order to improve students' educational outcomes, teachers help students to bring knowledge into mobile technology mainstream for using new pedagogical techniques (Aloraini, 2012). Positive effects of m-learning on learners' educational achievements can be observed through high learning quality, better understanding of the content, accomplished expected learning results, enhanced productivity during learning, inclination towards collective study, affirmative attitude towards the content or subject (Alqahtani \& Mohammad, 2015; MacCallum \& Jeffrey, 2009).

$\mathrm{Fu}$ (2018) stated that m-learning provides significant opportunities for learning, rather it delivers reliable circumstances that help student to develop meaning knowledge base. Kumar Jena and Pokhrel (2017) and Tai and Ting (2013) in their study found out positive impact of group m-learning practices on students' social interface, consistency and attention to seek knowledge and eventually academic performance. Mobile device is learning tool that opens up successful prospects and potential for university students to expedite their learning, improve learning styles and boost satisfaction in terms of both 
facilities and education (Twum, 2014). M-learning provides a constructivist educational environment that strengthens students to set their learning preferences through support of various mechanisms including verbal/visual, intuitive/sensing, reflective/active and global/sequential (Zare, Sarikhani, Salari, \& Mansouri, 2016). Students who use mobile devices exhibited higher levels of engagement, participation, cooperation and information. They spend greater time in doing research, assignments and learning as compared to those who use conventional educational tools. The similar outcomes are associated with learners studying independently, as they regard m-learning as a dynamic learning process that improves critical thinking, problem solving and innovative rationale (Ismail, Gunasegaran, Koh, \& Idrus, 2010). A number of research studies concluded positive impact of m-learning on scholastic output of students (Rashid \& Asghar, 2016; Huet \& Tcheng, 2010). In the light of literature following statement can be hypothesized:

Hypothesis 1: M-learning leads to enhance the students' academic performance in universities in Pakistan

\subsubsection{Effect of m-learning on students' academic performance with facilitation discourse as mediator}

Online learning is regarded as an active discussion and interaction platform for effective productivity and learning of students. However, there are some impediments that students usually face when seek knowledge through electronic media (Balaji \& Chakrabarti, 2010). This happens due to lack of one-to-one interaction and lack of opportunity for discussion and feedback. Mobile learning is one of the innovations of $21^{\text {st }}$ century that has created ease and adaptability for distant learning by incorporating supportive role of instructors (Yousuf, 2007). According to Karacapilidis and Papadias (2001) cooperative discourse or dialogue can play vital part in managing those obstructions. It has been found out that mobile assisted learning resources tend to broaden the prospects for students to sensibly consider their thoughts and undergo dialogue or discussion with the pertinent individuals, especially instructors (Laves, 2010; Anderson, 2004). This leads to personalize each student's learning and let the individual encounter facilitation advancement of embedded learning and establish new frames of knowledge structure (Balaji \& Chakrabarti, 2010). In order to promote facilitation discourse, m-learning gives rise to random communications between student and teacher that provide maximum discretion by encouraging leaners to attain knowledge at their own stride, having interest and background knowledge (Kupczynski, Ice, Wiesenmayer, \& McCluskey, 2010). The teacher plays the role of facilitator by organizing digitally broadcasted discussions with students, as lack of teachers' facilitation creates biggest challenge for sustained execution of m-learning (Qureshi, Ilyas, Yasmin, \& Whitty, 2012), provide opportunity to experience discourse and conduct assessments for enhancing educational productivity (Lowenthal, 2016).

Teacher's role become quite effective in managing utilization of explanatory video cases for long-term retention of knowledge and development of problem-solving skills (Shimada, 2017). Instructors' initiated discussions and discourse are supporting environmental factors that boost learning and academic excellence of students (Stark, Lassiter, \& Kuemper, 2013). The author also established that interaction dynamics of mobile-assisted learning strengthen the connectivity among students and course instructors, resulting in strong relationships between the two ends (Shackelford \& Maxwell, 2012). The extent of interaction in m-learning depends upon facilitation discourse that emerges through instructor's efforts and consequently leads to better understanding of the content by students (Osborne, Borko, Fishman, Gomez Zaccarelli, 
Berson, Busch, \& Tseng, 2019; Potter, 2013). In the underlying context, media richness theory helps to understand the mechanism of how interaction efficiency is enhanced by establishing correspondence between various mobile media gadgets of delivering content and learners' knowledge needs (Means, Toyama, Murphy, Bakia, \& Jones, 2009). Topchyan (2016) ascertained the intervening role of facilitation discourse and that teachers' instigated interactive session played an effective role in the phenomena of mlearning, eventually improving the overall scholastic performance of students. Zou, Xie, and Wang (2018) laid stress on instructor's critical role to assist students in various discourse strategies, enhance their constructive approach towards probing questions for better understanding, enhanced interactivity and improving critical thinking with experiential learning. Thus, m-learning promotes facilitation discourse that further empowering students to become their own knowledge agents and are able to perform better in assessments and practicality than before (Bereiter \& Scardamalia, 2014).

Teacher plays crucial part in facilitating dialogue through encouraging participation, allowing class submissions and inspiring to explore ideas (Shea, Li, Swan, \& Pickett, 2005). Integration of portable technology with education, highlights the significance of role played by teachers in acquiring updated pedagogical and technological skills that are essential for transforming the content of learning using Technological Pedagogical Content Knowledge (TPACK) (Sung, Yang, \& Lee, 2017; Koehler, Mishra, \& Cain, 2013). These pedagogical approaches help to enhance students' learning and satisfaction in distance online courses (Maulana, Opdenakker, \& Bosker, 2016; Shea et al., 2005). Facilitation discourse assists students in connecting with fellow students and collaborate for sharing ideas in online learning. This factor is supposed to be strongly linked to development of learning sense by students with support of mentors (Kiemer, Gröschner, Pehmer, \& Seidel, 2015; Gorham, 2010), thereby leading to improved assessment outcomes (Traxler, 2013; Swan \& Shea, 2005).

In a study by Faizi (2018), teachers tend to have better teaching proficiency while tutoring students using Web 2.0 mobile technologies, this also led development of positive students' learning perceptions. In todays' world, instructors prefer to incorporate interactive teaching pedagogy while actively working with technological devices that truly serve to promote blended and broadcasted learning (Hamm et al., 2013). Mobile technology is being used as a cutting edge technology for enabling the HEIs to deliver real time lectures to students, thus, realizing the real need of encouragement and assistance provided by the instructors for effective understanding (Pedro, de Oliveira Barbosa, \& das Neves Santos, 2018; Reinders \& Benson, 2017). The prime purpose of bringing blended learning into teaching methodology is to make learning environment more discussion-centered, interactive and encourage prompt feedback (Isbell, Rawal, Oh, \& Loewen, 2017; Reinders \& Benson, 2017). This helps students become more prudent in evaluating and diagnosing a particular situation (Sha, Looi, \& Chen, 2012; Cho, Lee, \& Jonassen, 2011).

The emergence of facilitation discourse in process of mobile learning helps to sharpen the scholarship and cognitive skills of students while eradicating the barriers of tangible affordances in shaping the contextual education experiences (Asiimwe, Grönlund, \& Hatakka, 2017). Facilitation discourse delivers a supporting role in learning via mobile technology and process-based pedagogy. Within the framework of m-learning, facilitation discourse and technology mediate to benefit students to develop meanings regarding understanding about the real world and interaction with the practical aspects (Kamarainen, Metcalf, Grotzer, Browne, Mazzuca, Tutwiler, \& Dede, 2013). Keeping in view the previous studies, following hypothesis statement has been deduced: 
Hypothesis 2: M-learning leads to emergence of facilitation discourse where, the instructor smooths learning by encouraging dialogue and communication that ultimately enhance students' academic performance

\subsubsection{Effect of m-learning on students' academic productivity with flexibility as mediator}

M-learning gives opportunity to obtain just-in-time and highly personalized learning that can be obtained anytime and anywhere (Emerson \& Berge, 2018). Flexibility is gained in terms of access to learning content and interaction with the teacher irrespective of time and location. The fast proliferation of ubiquitous learning using mobile technologies offers great opportunity for innovative learning, enabling students to be prepared for future (Panjaburee \& Srisawasdi, 2018). Mobile devices have greater academic potential that fulfill concerns for ubiquitous learning anytime and anywhere (Fuegen, 2012). Flexibility provides greater portability and accessibility for student and leaves affirmative impression of students' learning and supports inquiry-based understanding of the concepts (Chang \& Hwang, 2018). A huge population of students is facilitated for distant learning, benefiting from both the perspectives of pedagogy and scheduling. Students who gain virtual learning highly value flexibility, due to enhanced mobility and portability of mobile devices (Kumar Jena \& Pokhrel, 2017; Nie, Armellini, Witthaus, \& Barklamb, 2011). Integration of mobile devices with education is a tremendous collaboration that allows maximum learning flexibility for distant learners and teachers, while emphasizing the strength of connectivity and network between the two ends (Sulaiman \& Dashti, 2018). M-learning pedagogy delivers online learning with greater extent of flexibility, subsequently, m-learners take advantage of access to knowledge resources and digital learning content in mean time (Fakomogbon \& Bolaji, 2017). This flexibility generated as a result of mobile enabled education assists students in engaging in adaptive activities for coping up with the needs of dynamic learning (Hamdan \& BenChaban, 2013).

Flexible learning creates climate of learning empowerment, where all learners are regarded as "co-creators of knowledge", also give a way to conduct face-to-face virtual interactive sessions that boost learning (Niculescu, Rees, \& Gash, 2017). One of the significant characteristics of flexible learning is moving beyond the borders of formal education, hence, helping students to gain practical knowledge, execute theoretical concepts transform conventional learning to open learning (Li, 2018; Ryan \& Tilbury, 2013). Flexible learning provides students diverse choices concerning where, when and how to learn (Gordon, 2014) and assists in terms of interaction with instructor, time management, learning material and assessment (Palmer, 2011). Wireless connectivity inherently boosts flexibility for mean time communication and learning. These series of activities and characteristics lead to improved performance of learners scholastically and achievement of outstanding grades in their course assessment (Jacob \& Issac, 2014). Flexibility results in effective self-study, aids learners in seeking knowledge in just in time at their own stride and helps to retain information for longer time periods (Grenier, 2018). Resultantly, learners are able to apply their thoughts under different circumstances for resolving problems (Trifonova \& Ronchetti, 2006).

Students are able to tailor sources of receiving the knowledge content which allows for instant communication and feedback that further provides opportunity to students to ask questions, share ideas and resolve queries in real time (Ozdamli \& Uzunboylu, 2015). The results reveal that m-learning is an effective process of engaging students in meantime learning promoting behaviorally active knowledge seekers (Sarrab, 
2015). It extends flexibility for students and encourages them to study independently and focus solely on learning content (Hernández \& Pérez, 2014). Self-study as one of the outcomes of flexibility leads to enhance education scholarship of students (Alalwan, Alzahrani, \& Sarrab, 2013). Universities have realized the need to establish and execute wireless learning systems that deliver maximum extent of flexibility, which further promotes adaptability. This triggers spirit and dynamicity in the learning environment for energizing students who obtain education through M-learning mechanism. Flexibility is induced as an outcome of m-learning practices that activate learning by adapting to learners' behaviors and contexts (Li, Lee, Wong, Yau, \& Wong, 2017). Keeping in view the benefits of m-learning, institutions are switching from using single-role mobile gadgets to multiple-roles wireless technologies for strengthening adaptability and flexibility of overall learning system (Wong, 2014). They are focusing on apprehending and designing flexible framework that reinforces multiple tasks in single cordless device to sustain malleability in the overall system (Rambe \& Bere, 2013). The adaptability obtained through opens up avenues for innovative learning outcomes and learners' academic goals (Frohberg, Göth, \& Schwabe, 2009).

Enormous efforts are being done to operationally explore the impact of $\mathrm{m}$ learning on achieving flexibility by using resources adaptably and sharing resource with related learning actors (Pimmer, Mateescu, \& Gröhbiel, 2016). He qualitatively studied how m-learning generates flexibility for the students and teachers to use knowledge context for learning in particular context (Nestel, Gray, Ng, McGrail, Kotsanas, \& Villanueva, 2014). Adaptable sense making via use of portable technology helps to contextualize conceptions in specific settings for achieving targeted results (Liu, Li, \& Carlsson, 2010). This supports students to perform better in assignments and tasks that involve higher levels of critical thinking (Wai, $\mathrm{Ng}$, Chiu, Ho, \& Lo, 2018). Findings of these studies illicit the mediating role of flexibility in effect of m-learning on students' academic achievements (Wai et al., 2018; Liu et al., 2010). Following statement is hypothesized:

Hypothesis 3: M-learning helps to improve the students' productivity in education and learning while promoting the flexibility in terms of access to content, time and space

\subsection{Diagrammatic model}

After critically reviewing and analyzing the theoretical framework of the relationship between independent, mediating dependent variables, the conceptual framework developed is represented in Fig.1.

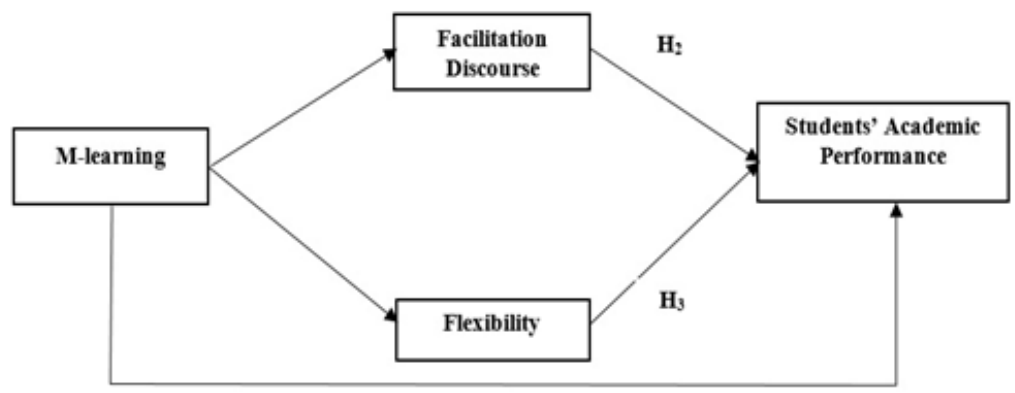

$\mathbf{H}_{1}$

Fig. 1. Conceptual diagram 


\section{Research design and methodology}

Current study is quantitative, correlational and cross-sectional research that aims to understand relationship between m-learning, facilitation discourse, flexibility and students' academic performance. Using the deductive research strategy, the purpose is to examine whether m-learning has a direct significant positive effect on scholarly performance of students and to test the mediating effects of facilitation discourse and flexibility on the direct relationship.

\subsection{Procedure of population and sampling}

\subsubsection{Population}

The population of current study comprises of students enrolled in private sector universities in Lahore, Pakistan. In the light of current study, the aim is to examine the perceptions of students who own and use mobile gadgets, belonging from upper and middle class. As they are able to afford smartphones, therefore, they were purposefully selected for data collection. The sampling frame of the students could not be accessed to due to reluctance of university administration for sharing names of currently enrolled students and online unavailability of their list. To opt the target population, it was made sure that individuals in sampling frame were actually involved in m-learning. Currently, in Private sector universities, all students use mobile and portable devices to access learning material anywhere within campus or outside (Hameed \& Qayyum, 2018). They can directly access lecture notes, presentation slides and assignments via the online portals where the instructor guides about how to practice and grab learning. Students are used to discuss lectures through social media apps and explore topics via the internet technology (Wong, Wang, Ng, \& Kwan, 2015).

\subsubsection{Sampling}

Due to inaccessibility of students' list, simple random sampling technique was used to select sample of students from a total of 580 students. Appropriate number of questionnaires according to population size were distributed among students studying in the HEIs in Lahore, Pakistan. Penwarden (2013) established that in case of absence of correct sampling frame and to reduce researcher's bias, raised due to difference between the actual population and that expressed by the explorer, it is applicable to gather data from individuals present at that time period. Therefore, students available at the time of data collection were randomly given the survey questionnaire (Trochim, 2008). Data was collected from a total of 203 students, which also met the threshold requirement of data sets for executing structural equation model.

\subsection{Data collection}

The eventual goal of the research study is to explore the cause and effect of the predictor variables on outcome variables and learn new phenomena that can be established through perceptions of respondents (Driscoll, 2011). This also aims to eliminate researcher's bias in the research process. Hence, for this purpose, the primary data collection method was used. The approach used in this study was self-administered questionnaire which asked students about perceptions and behaviors regarding the variables under study. The survey comprised of two sections for primary data collection, section I contained nominal scales 
to obtain demographic data of learners, whereas, section II included instrument items to measure perceptions on 5-point Likert scale. The data was gathered from a total of 203 respondents using survey questionnaire and were informed about purpose of research and ensured regarding confidentiality of their responses.

\subsubsection{Ethics and informed consent}

All study participants gave their informed consent for completion of survey. They were given the right to reject participation without any retribution and were acknowledged about confidentiality and privacy of their responses in written. Students gave voluntary consent with being able to exercise influence without force and coercion, moreover, students were guided regarding the contents of questionnaire that would have made them able to make rational choices.

\subsubsection{Demographics}

Demographic included profile characteristics of students in universities in Pakistan. The percentages and frequencies of demographic items are exhibited in Table 1. It was found that the percentage of male respondents was $53.7 \%$ having frequency 109 while, $46.3 \%$ females with frequency of 94 participated in the survey. $44.3 \%$ of students laid in age group of up to 25 years with frequency $90,38.9 \%$ of respondents were in age group of 26-30 years having frequency of 79 and $15.8 \%$ of the students had ages between 31--35 years displaying frequency of $32,1 \%$ students with a frequency of 2 lied in age group of 36-40 years, however no student lied in the age group above 40 years. $34.5 \%$ students reported to be current student of bachelor program with a frequency of $70,59.6 \%$ presenting incidence of 121 informed that they are currently enrolled in Master program, whereas, only $5.9 \%$ were found to be post-graduate degree students exhibiting occurrence of 12 . $47.8 \%$ students with frequency of 97 were found to employed, while, $52.2 \%$ students displaying occurrence of 106 were reported as unemployed.

\section{Table 1}

Demographics (No. of respondents $=203$ )

\begin{tabular}{rrr}
\hline Varaibles & Percentage & Frequency \\
\hline Gender & & \\
Male & $53.7 \%$ & 109 \\
Female & $46.3 \%$ & 94 \\
Age & & 90 \\
Up to 25 years & $44.3 \%$ & 79 \\
26-30 years & $38.9 \%$ & 32 \\
$31-35$ years & $15.8 \%$ & 2 \\
$36-40$ years & $1 \%$ & 0 \\
$41-45$ years & $0 \%$ & 0 \\
$46-50$ years & $0 \%$ & 70 \\
Education & & 121 \\
Bachelor's & $34.5 \%$ & 12 \\
Master's & $59.6 \%$ & \\
PhD & $5.9 \%$ & 97 \\
Employment & & 106 \\
Employed & $47.8 \%$ & \\
Unemployed & $52.2 \%$ & \\
\hline
\end{tabular}




\subsection{Measurement instruments}

The questionnaire consisted of two sections, the first involved items regarding respondents' demographic profile, whereas, section two comprises of 5-point likert scale items of instruments. Following is the description of demographic items and each instrument used for quantitative data collection through survey.

\subsubsection{Demographic instrumentation}

The unit of analysis for current study was students enrolled in universities in Lahore. Keeping in view the significance of demographic dynamics, it was deemed important to examine the demographic outline of the respondents. The items included gender, age, qualification and employment.

\subsubsection{M-learning}

The students' perceptions of m-learning were measured on 5-point Likert scale ranging from 5 (strongly agree) to 1 (strongly disagree). The 5 items' scale was adapted from AlHajri, Al-Sharhan, and Al-Hunaiyyan (2017). The scale was previously developed and adapted from Al-Fahad (2009), in which effectiveness of m-learning was evaluated through students' perceptions and attitudes concerning mobile learning. Georgieva, Smrikarov, and Georgiev (2011) also used the scale items for assessing the m-learning effectiveness. The scale of m-learning included items such as the use of social media applications helps in educational attainment; use of social media helps to strengthen the communication with others; learning by mobile helps me learn anytime, anywhere; learning by mobile opens many ways to learn and provide various learning fields and $\mathrm{m}$ learning helps me to share information with other students.

\subsubsection{Facilitation discourse}

The students' perceptions of facilitation discourse emerged as a result of mobile assisted learning were measured on 5-point Likert scale ranging from 5 (strongly agree) to 1 (strongly disagree). The 5 items' scale was adapted from Shea et al., (2005). The scale was previously established with support of Anderson, Liam, Garrison, and Archer (2001). The respondents' perceptions about instructor's ability to identify areas of harmony and discord; to persuade for endorsement and understanding; to stimulate, recognize and strengthen students' accomplishments; to create a learning culture; to promote discussion and discourse and to evaluate efficiency of teaching process (Shea et al., 2005). The instrument comprised of items such as the instructor is helpful in identifying areas of agreement and disagreement on course topics that assist me to learn; instructor is helpful in guiding the class towards understanding course topics in a way that assist me to learn; instructor acknowledges student participation in course; instructor encourages students to explore new concepts in course and instructor helps keep students engaged and participating in productive dialogue.

\subsubsection{Flexibility}

Students' perceptions of flexibility due to mobile learning were measured on 5-point Likert scale ranging from 5 (completely true) to 1 (not true at all). The 5 items' scale was adapted from Clarke and James (1998) and was used by Bergamin, Ziska, Werlen, and Siegenthaler (2012) to measure perception of students about m-learning within and 
outside the classroom. Scale consisted of items such as I can decide when I want to learn; I can arrange the learning time; I can contact the teacher at any time; I can prioritize topics in my learning and I can choose between different learning forms, including oncampus study, online study, and self-study.

\subsubsection{Students' academic performance}

The students' academic performance was measured on 5-point Likert scale ranging from 5 (strongly agree) to 1 (strongly disagree). The 5 items' scale was adapted from Kasantra et al. (2013). Martha (2009) and Joyce and Yates (2007) used this scale to quantify the responses of students' perception about their educational achievements. The items for examining perceptions of students' performance included, I often repeat a year/semester or carry modules over next academic year/ semester; since starting university studies, I have never ever failed an examination; I did not perform poor in my past semester examinations; I am good in most of my modules/courses and I am able to achieve the academic goal that I have set.

\section{Results and interpretation}

\subsection{Data analysis}

After data collection from respondents, the survey items were rated using SPSS. The frequencies of nominal variables, descriptive statistics including percentages, standard deviations and means of categorical variables and descriptive, reliability, validity and correlations were analyzed using SPSS. Structural Equation Modeling in AMOS was used to test the causal relationships and mediation effects of the variables. The responses were collected from a total of 203 respondents having no missing value.

\subsubsection{Descriptive analysis}

The descriptive statistics of quantitative variables comprised of minimum, maximum, standard deviation, mean, kurtosis and skewness values are presented in Table 2. The maximum value for all the variables was 5 , whereas, the minimum was 1 . The mean and standard deviation values of students' perceptions about m-learning were 4.35 and 0.783 respectively. A negative value of skewness i.e. -1.582 specified smaller value of mean than median. The kurtosis of variable had positive value of 2.556 which indicated higher peak than normal distribution of the data. For facilitation discourse, there was mean value of 4.08 and standard deviation of 0.996 . The skewness for facilitation discourse was -1.254 , exhibiting that median is greater than mean. The kurtosis displayed positive value of 0.889 showing high peak of normal distribution. The students' perceptions for flexibility displayed observed mean of 4.08 with standard deviation of 0.958 . The extent of probability distribution of flexibility, i.e. skewness had negative value of -1.155 which exhibited that mean is smaller than median. The peak of curve of normal distribution was found to be higher and was represented by positive kurtosis value of 0.854 . Finally, for students' academic performance, points in normality distribution displayed the mean value of 4.39 and standard deviation of 0.772 . The measure of skewness had negative value of -1.845 showing mean lesser than median, whereas, the kurtosis value was 1.455 displaying shorter tails and moderate peak of normality distribution curve. 
Table 2

Descriptive statistics

\begin{tabular}{|c|c|c|c|c|c|c|c|c|}
\hline \multirow{2}{*}{ Variables } & \multirow{2}{*}{ Min. } & \multirow{2}{*}{ Max. } & \multirow{2}{*}{ Mean } & \multirow{2}{*}{ Std. Dev. } & \multicolumn{2}{|c|}{ Skewness } & \multicolumn{2}{|c|}{ Kurtosis } \\
\hline & & & & & Statistics & SE & Statistics & SE \\
\hline M-learning & 1 & 5 & 4.35 & .78 & -1.58 & .076 & 2.56 & .745 \\
\hline $\begin{array}{c}\text { Facilitation } \\
\text { discourse }\end{array}$ & 1 & 5 & 4.08 & .10 & -1.25 & .076 & 0.89 & .745 \\
\hline Flexibility & 1 & 5 & 4.08 & .96 & -1.16 & .076 & 0.85 & .745 \\
\hline $\begin{array}{c}\text { Students' } \\
\text { academic } \\
\text { performance }\end{array}$ & 1 & 5 & 4.39 & .77 & -1.85 & .076 & 1.46 & .745 \\
\hline
\end{tabular}

\subsubsection{Test for normality}

Normality of the variables was explored by two means i.e. interpretation of statistical values of skewness and kurtosis and testing the normality assumption. Using skewness and kurtosis measures for normality, a normal distribution is indicated by 0 score. As reported by expert statisticians, standard error is used for kurtosis and skewness values using SPSS (Field, 2013; Pallant, 2013; Kres, 2012). Applying rule of thumb of dividing each of skewness and kurtosis value by respective standard error and obtaining result that laid within the range of \pm 1.96 suggested that the data was normally distributed. The outputs are given in Table 2 .

\subsubsection{Reliability and validity}

The reliability explaining the internal consistency among items of each scale was determined from statistics of Cronbach's Alpha and significance of p-values (Sahu, Pal, $\&$ Das, 2015). The range of Cronbach's Alpha value lies from 0 to 1 , whereas, a value of 0.7 or above represents higher reliability for a particular scale (Sahu et al., 2015). The validity was confirmed through KMO value whose range lies between 0 and 1, however, Sahu et al. (2015) established that its value must be higher than 0.5. Other determinant of validity was Bartlett Test of Sphericity that measures inter-item correlation. The reliability and validity statistics of interval scales are exhibited in Table 3.

Table 3

Reliability and validity statistics of instruments

\begin{tabular}{ccccc}
\hline Scales & Cronbach's Alpha & KMO Value & Chi-Square & P-Values \\
\hline M-learning & $.90^{*}$ & $.84^{*}$ & 232.22 & .000 \\
\hline $\begin{array}{c}\text { Facilitation discourse } \\
\text { Flexibility }\end{array}$ & $.95^{*}$ & $.90^{*}$ & 361.78 & .000 \\
\hline $\begin{array}{c}\text { Students' academic } \\
\text { performance }\end{array}$ & $.90^{*}$ & $.85^{*}$ & 237.04 & .000 \\
\hline Note. & $.77^{*}$ & $.77^{*}$ & 145.24 & .000 \\
\hline
\end{tabular}




\subsubsection{Correlations}

The correlation coefficient or Pearson coefficient " $r$ " was used to measure degree of strength of relationship between two variables. " $r$ " involves direction and magnitude of the relationship between two variables (Taylor, 1990). The values range from -1 to 0 to $+1,0$ value represents no association between two underlying study variables (Taylor, 1990). The closer the value of " $r$ " to \pm 1 irrespective of the direction of relationship, the stronger the linear relationship between two variables. Sign indicates positive or negative effect of one variable on the other. The significance of relationship between two variables is represented by $\mathrm{p}<.05$ (Taylor, 1990). The values of Pearson's correlation coefficient and values of significance level for relationship between independent and dependent variables are given in Table 4.

Table 4

Correlation among the variables

\begin{tabular}{|c|c|c|c|c|c|c|c|c|c|}
\hline Variables & Mean & $S D$ & Loadings & $C R$ & $A V E$ & $M L$ & $F D$ & $F l$ & $S A P$ \\
\hline M-learning & 4.35 & .783 & $.74-.85$ & .79 & .62 & 1 & & & \\
\hline Facilitation discourse & 4.08 & .996 & $.79-.87$ & .87 & .59 & $.61 * *$ & 1 & & \\
\hline Flexibility & 4.09 & .958 & $.81-.86$ & .76 & .68 & $.69 * *$ & $.64 * *$ & 1 & \\
\hline $\begin{array}{l}\text { Students' academic } \\
\text { performance }\end{array}$ & 4.39 & .772 & $.83-.89$ & .91 & .55 & $.59 * *$ & $.66 * *$ & $.52 * *$ & 1 \\
\hline
\end{tabular}

The correlation statistics representing the association between m-learning and students' academic performance was .00 i.e. $p<.05$ indicating a significant association between the constructs. Pearson's correlation coefficient value was found to be $r=.59$. The value of " $r$ " represented a good correlation between both variables, whereas, positive sign showed significant positive linear relationship between students' perceptions of learning through mobile phones and their relative education performance. The association between m-learning and facilitation discourse was significant at .00 i.e. $p<.05$, moreover, Pearson's correlation coefficient value was $r=.61$. The value of " $\mathrm{r}$ " was greater and near to +1 indicated a high correlation between both the constructs. The positive sign of " $r$ " exhibited existence of significant positive linear relationship and direction of association between m-learning and facilitation discourse. The statistics of correlation between m-learning and flexibility was .00 i.e. $p<.05$ demonstrating significant association between the constructs. The value of correlation coefficient " $r$ " was .69. The higher value and positive sign represented significant positive correlation between both the constructs. The correlation between facilitation discourse and flexibility was significant .00, highlighting strong association between the constructs. The value of " $r$ " equal to .64 displayed significant positive linear relationship between both variables. The association between facilitation discourse and students' academic performance was substantial at 0.000 . Pearson's correlation coefficient was found to be $r=.66$ which indicated good correlation between both the constructs. The value of Pearson's correlation coefficient for relationship between the flexibility and student's academic performance was 0.517 significant at .00 i.e. $p$.05. This indicated significant association and positive direction of relationship between the constructs. 


\subsubsection{Validating measurement model through confirmatory factor analysis (CFA)}

Convergent and discriminant validities of model, determined through CFA, exhibited that values of Average Variance Extracted (AVE) were greater than values of Composite Reliability (CR). This proved the existence of convergent validity among the constructs. The results of CFA for examining the convergent validity met the cutoff levels i.e. CR > 0.7 ranging from 0.79 to 0.91 , illustrated by Raykov (2011). It was also proved by the findings that values of factor loadings were above 0.6 (Raykov, 2011). The values of AVE were found to be greater than 0.5 , i.e. ranging between 0.55 to 0.68 , and less than CR, thus laying within prescribed range of cutoff level expressed by Raykov (2011). As observed from findings, the values of AVE were greater than that of correlation among the variables, thereby, displaying discriminant validity (Fornell \& Larcker, 1981). The results of convergent and discriminant validity are displayed in Table 4.

\subsubsection{Testing for common method variance}

Keeping in view the cross-sectional design and concern for Common Method Variance, due to collection of data for independent and dependent variables from same unit of analysis or set of respondents (Jakobsen \& Jensen, 2015), it was deemed important to test CMV. CMV arises due to inception of systematic variance into survey instruments through measurement approach (Doty \& Glick, 1998) and appears as an error variance split among all variables when responses are gathered from same set of respondents. This error leads to occurrence of CMV which further cause biasness in associations among the variables under study (Richardson, Simmering, \& Sturman, 2009). This common method acts as a variable that influences the relationships among the study variables, this hampers the estimated associations among the variable (Jakobsen \& Jensen, 2015). For effective practical implications, it is essential to have accurate quantification of respondents' perceptions and attitudes (Yüksel, 2017). Contrary to it, biasness in respondents' opinions can raise serious reservations on the generalizability of the results (Yüksel, 2017). CMV critically impacts the results of study if not appropriately administered. One way to control CMV and remove biasness is to implement statistical rectifications in data analysis (Tehseen, Ramayah, \& Sajilan, 2017). Tehseen et al. (2017) elaborated most commonly used statistical approaches to test and control CMV, including Partial Correlation Procedures; Harmen's Single-Factor Test; Correlation Matrix Procedure and Latent Marker Variable Approach.

In this study, Correlation matrix procedure has been used. According to Bagozzi, Yi, and Phillips (1991) this method measures the effect of CMV through correlations among the latent variables. With the help of this technique, CMV is observed if significant large values of correlations i.e. Pearson correlation statistics " $r$ " is greater than 0.9. Contrarily, values of correlation " $\mathrm{r}$ " less than 0.9 demonstrate that CMV is not a major problem in the research study (Bagozzi et al., 1991). Table 4 shows the correlations among the variables. The results of analysis revealed that all values of " $r$ " are less than 0.9, which proved absence of CMV and biasness in the variable measurement.

\subsubsection{Structural equation modeling}

Structural Equation Modeling (SEM) is the adjunct of GLM (General Linear Model) that allows for simultaneously testing a number of relationships among the variables and regression calculations. The pattern formed in the structural model explained associations among latent variables which were connected through head arrows. The outcomes of the 
SEM and the structural model are interpreted below. The values of the standardized beta coefficients and significance level for relationship between independent and dependent variables have been explained. The structural model obtained as SEM in displayed in Fig. 2.

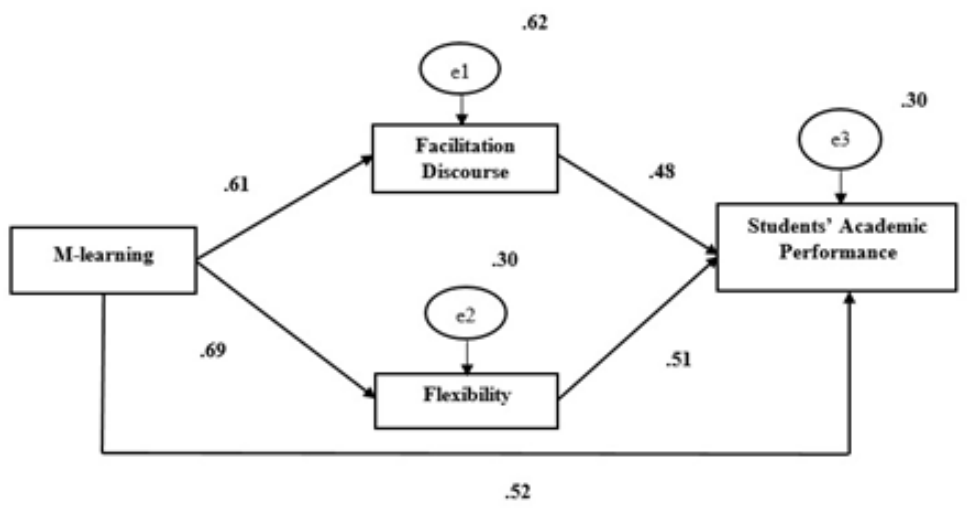

Fig. 2. Structural model and model path diagram

\subsubsection{Model fit}

The model fit was determined by analyzing the outcomes or fit indices of SEM indicating the measure of fitness i.e. CMIN/DF, GFI, RMR, RMSEA and PCLOSE values. The statistical values of fit measures were compared with their respective cutoff levels and are displayed in Table 5. The results revealed that the fit measures lied within the acceptable ranges as established by Gaskin (2013) and Hair, Sarstedt, Ringle, and Mena (2012). such as CMIN/DF came out to be 1.249 less than 5 and significant at $\mathrm{p}<0.05$, RMR value was found to be 0.024 less than 0.05 , GFI measure of model fit was observed to be 1.331 greater than 0.9. Adjusted Goodness-of-fit Index AGFI regulates the value of GFI through degrees of freedom and saturated model for model reduction, had value above 0.9 i.e. 2.115, thus met the cutoff level (Tabachnick \& Fidell, 2007). RMSEA was determined to be 0.04 less than 0.1 with an insignificant value of PCLOSE i.e. 0.658 (Gaskin, 2013; Hair et al., 2012). Normed Fit Index (NFI) evaluates the model through comparison between model's chi-square value to that of the chi-square value of null model, having statistical value range varying between 0 to 1 . Value nearer to 1 indicated good fitness of model, however, NFI value was found to be 0.731 (Bentler \& Bonnet, 1980). Non-Normed Fit Index (NNFI), a statistic used for smaller samples specified a value of 1.477 , greater than 0.9 which indicated good fitness of model (Tabachnick \& Fidell, 2007; Schreiber, Nora, Stage, Barlow, \& King, 2006).

\subsubsection{Effect of m-learning on students' academic performance}

The outcomes of structural equation modelling identified the variation in students' academic performance explained by its linear relationship with mobile learning. The results suggested that m-learning had positive relationship with students' academic performance $(\mathrm{B}=0.520)$, having significant $p$-value $=0.020$ i.e. $p<0.05$. For an increase in the value of m-learning by one unit, the academic productivity of students increased by 0.520 , keeping other factors constant. The value of standardized estimate $(\beta)$ for this effect was found to be 0.302 , indicating the relationship between the two 
variables. The positive value of $\beta$ reported positive relationship between m-learning and students' academic performance. The results led to conclude that mobile assisted learning play significant positive role in enhancing the overall educational achievements of students, thus rejecting the null hypothesis. The results are exhibited in Table 6.

Table 5

Model fit measures

\begin{tabular}{|c|c|c|c|c|}
\hline \multicolumn{2}{|c|}{ Model Fit Measures } & Fit Indices & Results & Reference \\
\hline \multirow{4}{*}{$\begin{array}{l}\text { Absolute fit } \\
\text { measures }\end{array}$} & $\begin{array}{c}\text { CMIN/DF (Chi- } \\
\text { Squared/degree of } \\
\text { freedom) }\end{array}$ & $\leq 5$ & 1.25 & \multirow{3}{*}{$\begin{array}{l}\text { Gaskin (2013); Hair } \\
\text { et al. (2012) }\end{array}$} \\
\hline & $\begin{array}{l}\text { RMR (Root Mean Square } \\
\text { Residual) }\end{array}$ & $\leq .05$ & .02 & \\
\hline & $\begin{array}{l}\text { GFI (Goodness-of-fit } \\
\text { Index) }\end{array}$ & $\geq .9$ & 1.33 & \\
\hline & $\begin{array}{c}\text { AGFI (Adjusted } \\
\text { Goodness-of-fit Index) }\end{array}$ & $\geq .9$ & 2.12 & $\begin{array}{c}\text { Tabachnick \& Fidell } \\
\text { (2007) }\end{array}$ \\
\hline \multirow{4}{*}{$\begin{array}{l}\text { Fit measures based } \\
\text { on non-central Chi- } \\
\text { square distributions }\end{array}$} & $\begin{array}{l}\text { RMSEA (Root Mean } \\
\text { Square Error of } \\
\text { Approximation) }\end{array}$ & $\leq .1$ & .04 & \multirow{2}{*}{$\begin{array}{l}\text { Gaskin (2013); Hair } \\
\quad \text { et al. (2012) }\end{array}$} \\
\hline & $\begin{array}{l}\text { P-CLOSE (RMSEA } \\
\text { significance) }\end{array}$ & $\geq .05$ & .66 & \\
\hline & Normed Fit Index (NFI) & $\leq 1$ & .73 & \multirow{2}{*}{$\begin{array}{l}\text { Tabachnick \& Fidell } \\
\text { (2007), Schreiber, } \\
\text { Nora, Stage, } \\
\text { Barlow, \& King } \\
\text { (2006) }\end{array}$} \\
\hline & $\begin{array}{l}\text { Non-Normed Fit Index } \\
\text { (NNFI) }\end{array}$ & $\geq .95$ & 1.48 & \\
\hline
\end{tabular}

Table 6

Results of structural equation modelling ( $\mathrm{N}=203)$

\begin{tabular}{|c|c|c|c|c|c|c|c|}
\hline$D V$ & $I V$ & Un-std. B & $S E$ & $S t d . \beta$ & $C R$ & $P$ & (Ho Rejected $)$ \\
\hline$F D$ & ML & $.61 *$ & .12 & 0.61 & 6.624 & .000 & Rejected \\
\hline SAP & FD & $.48^{*}$ & .08 & 0.48 & 4.632 & .000 & Rejected \\
\hline SAP & ML & $.52^{*}$ & .13 & 0.30 & 2.327 & .020 & Rejected \\
\hline \multicolumn{2}{|c|}{$\begin{array}{c}\text { Indirect Effect/Mediation } \\
M L-F D-S A P\end{array}$} & $.30^{*}$ & & & & .000 & Rejected \\
\hline Flex. & ML & $.69 *$ & .10 & 0.69 & 8.349 & .000 & Rejected \\
\hline SAP & Flex. & $.51^{*}$ & .09 & 0.46 & 3.04 & .030 & Rejected \\
\hline$S A P$ & ML & $.52 *$ & .12 & 0.30 & 2.327 & .020 & Rejected \\
\hline $\begin{array}{r}\text { Indirect } \\
M I\end{array}$ & $\begin{array}{l}\text { Mediation } \\
\text { SAP }\end{array}$ & $.28^{*}$ & & & & .000 & Rejected \\
\hline
\end{tabular}

Note. $X^{2}=11.954 ; *$-value $<.05$ 


\subsubsection{Effect of m-learning on students' academic performance, mediating role of facilitation discourse}

Mobile integrated learning was found to have a direct and significant impact on facilitation discourse having unstandardized coefficient value of $B=0.608$ having $p$ value less than 0.05 . This interprets that when students use mobile devices for learning purpose the role of course instructor becomes essential in facilitating content learning, discussion and dialogue among students and teachers by 0.61 , not keeping in account the variation in other elements. Likewise, the effect of facilitation discourse students' academic performance was also found to be positively significant exhibiting standardized $\beta=0.48$. This led to accomplish that having an effective participation of instructor in enabling communication and understanding of content for students their academic performance consequently increases by 0.48 , not catering deviation in any other factor. The results demonstrated positive standardized $\beta$ values for relationship between $\mathrm{m}$ learning and facilitation discourse i.e. 0.608. Similarly, positive relationship between facilitation discourse and students' academic performance was validated by $\beta=0.478$.

\subsubsection{Mediation test for path analysis}

The mediation or path analysis was examined through SEM executed in AMOS as a result of Multivariate Analysis. It was found that, while the direct effect of m-learning was significant on educational performance of students; the indirect effect of m-learning on student educational achievements in presence of facilitation discourse confirmed the significant mediation effect. The outcomes of path analysis have been displayed in Table 6.

\subsubsection{Interpretation of path analysis}

The conclusions of path analysis suggested that m-learning was found to be significant in predicting the hypothesized mediating variable i.e. facilitation discourse $(\beta=0.608)$ with $p$-value $=0.000$ i.e. $p<0.05$. Moreover, the analysis of direct effect of mobile-learning on students' learning performance controlling for facilitation discourse revealed that $\mathrm{m}$ learning had positive effect on student' performance $(\mathrm{B}=0.520)$ with significant $\mathrm{p}$-value i.e., $p=0.007$ i.e. $<0.05$. When controlling for the $\mathrm{m}$-learning, facilitation discourse displayed positive impact on academic achievements of students having a significant pvalue of $p=0.000<0.05$. The total effect model summary showed that m-learning had a positive relationship with students' academic productivity with significant $\mathrm{p}$-value of $p=$ 0.000 i.e. $p<0.05$. The results for indirect effect of the path analysis indicated that the standardized beta coefficient had positive value of 0.301 with significant $p$-value $=$ 0.000. The outcome of path analysis led to conclude that mediation proved to be statistically significant. This suggested that facilitation discourse has a mediating effect on the relationship between m-learning and students' academic performance. Hence, the results rejected the null hypothesis and established that facilitation discourse boosts the impact of m-learning on performance of students in Universities of Pakistan.

\subsubsection{Effect of m-learning on students' academic performance, mediating role of flexibility}

The outcomes of multivariate analysis using SEM, suggested direct and significant impact of mobile assisted learning on flexibility in regard of time, accessibility and place, displaying unstandardized beta coefficient value of $\mathrm{B}=0.694$ with $p$-value $<0.05$. This 
ascertains the fact that using mobile phones helps students to learn the content regardless of space and time which increases their performance by 0.69 , keeping other elements constant. Similarly, the flexibility tends to have positive effect on students' academic performance revealing standardized $\beta=0.51$. It was accomplished that students having the benefit of flexible learning re able to score superior grades in their course work, thus increasing performance by 0.51 , exclusive of deviation in other components. Value of standardized $\beta$ for relationship between m-learning and flexibility was found to be 0.694 and that of flexibility and students' academic performance was 0.457 . These $\beta$ values exhibited positive relationship between the stated variables.

\subsubsection{Mediation test for path analysis}

The path analysis for testing mediation of flexibility on the relationship between mlearning students' academic accomplishments was determined through multivariate analysis in SEM. The indirect effect of m-learning on students' academic productivity, in the presence of flexibility indicated significant mediation effect.

\subsubsection{Interpretation of path analysis}

The estimates of path analysis unveiled that m-learning was found to be significant predictor of theorized mediating variable i.e. flexibility having significant standardized beta estimate of $\beta=0.69$. Furthermore, controlling for flexibility, the m-learning significant increases students' accomplishments $(B=0.520)$. When controlling for the $\mathrm{m}$ learning, flexibility displayed positive impact on academic achievements of students having a significant p-value of 0.000 . The model summary of total effect highlighted direct affirmative association between m-learning and students' academic performance with $\mathrm{p}=0.000$ i.e. $p<0.05$. The indirect effect of the path analysis showed positive value of standardized coefficient $(\beta=0.278)$ significant at 0.000 . The results confirmed statistical significance of mediation effect. Therefore, the outcome rejected null hypothesis and determined that flexibility strongly boosts the effect of mobile phone assisted learning on the productivity of students' throughout the academic cycle in HEIs in Pakistan.

\subsubsection{Squared multiple correlation estimate}

The estimate of square multiple correlation indicating coefficient of determination " $\mathrm{R}$ " described the goodness of model fit and presents the magnitude of deviation in predictor variable due to divergence in value of explanatory variable. The observed statistic of $\mathrm{R}^{2}=$ 0.691 described that $69.1 \%$ variation in students' academic performance is explained by its relationship with mobile learning, facilitation discourse and flexibility. The value of chi-square was found to be 11.954 which proved that the proposed model cannot be rejected.

\section{Discussion}

The education management sector strives to do better, however, one of the hallmarks of this industry is advent of technological innovation through e-learning, which is now more commonly referred as mobile learning. M-learning, as significant outcome of electroniclearning, has transformed the way academicians teach and scholars or students learn (Glenn, 2008). The way educationists are equipping learners with key knowledge, 
concepts and theories can play significant role in making them highly effective in their academics and ultimately make them capable of competing in globalized economy (Selwyn, 2010). In today's era, universities and educational institutions are striving to embrace the evolutionary benefits and opportunities for integrating mobile technology and academia all around the globe (Straub, 2009). Mobile technology, critical for agile learning, is being greatly realized in Asia, specifically in Pakistan. Among all mobile users there is broad space captured by students and academic scholars to obtain education through mobile technology. Previous research studies had been based on studying the direct effect of M-learning on academic accomplishments of students and implications on students' learning through M-learning (Sung et al., 2016). The underlying study investigated the effect of m-learning on productivity of students via facilitation discourse and flexibility as mediators. Moreover, regardless of gender biasness, education level and employment status, learners retain strong motivation for using technology to get quick, timely and accurate knowledge for outstanding scholastic accomplishments. The results of each path are discussed separately.

\subsection{M-learning and students' academic performance}

The outcomes of the study demonstrated that m-learning has a significant positive effect on performance of students in universities in Pakistan. M-learning was found to be more effective in supporting students to achieve best learning outcomes and improve their performance than traditional learning approaches. It was apparent that students who gained education through m-learning displayed better comprehension and understanding of course contents that their academic fellows' capabilities. Impact of mobile education on performance of students has been visualized as success of technology assisted learning. M-learning has made education fast and easy without causing constraints of time and location. The fact that students are effective in discussing the topics and interacting with instructors and peers at any time and place. M-learning enhances students' productivity, which has led to establish that these learners effectively utilize their off or leisure time for exploring learning material and transformed idle time into productive hours. The process has added to provide sustenance via interactive learning and coaching characteristics that have made students dynamic through active interface with educational material and teacher using mobile gadgets. The ubiquitous and flexible learning provided by mobile technology has enriched students' conversational capabilities and led them to accomplish their academic objectives. It provides opportunity for learners to self-study as they can experience independent learning, which also makes unchallenging for mentors to distinguish one student from others. The results inferred that contextualization and impulsiveness offered by m-learning have made process student-focused, thus, inclining them towards independently retrieving content and interact with instructor through internet. The outcome is dramatic improvement in student grades in the enrolled courses as they receive knowledge from infinite online sources and make strategic use of the information.

The findings of this study revealed that improvements in scholastic performance of learners proved the promising use of mobile learning while creating a significant impact (Sung \& Mayer, 2013; Froese et al., 2012). Assimilation of mobile devices in education result in achievement of higher grades compared to those who obtained learning through orthodox theoretical or text book mode of instruction (Huang et al., 2010). The results of current study are consistent with the favorable conclusions made by $\mathrm{Lu}$ (2008), who found momentous interest of learners to use mobile technology for learning as they perform better when compared to paper or text book learning 
environment. Students exhibit positive transformation in their learning behaviors and outcomes when exposed online learning practices. Therefore, incorporation of mobile learning in classroom environments and independence of study at any place create learners' affirmative perceptions about their educational accomplishments (Navaridas et al., 2013).

\subsection{M-learning and facilitation discourse for improved students' academic performance}

The results of analysis confirmed significant positive impact of m-learning on students' academic performance mediated by facilitation discourse. Use of mobile technology stimulates instructors to facilitate and guide students in obtaining the core knowledge and understanding about the content. This ultimately boosts students' capability of performing well. The outcomes of correlation analyses displayed significant positive associations between the three latent variables. Structural Equation Model analyzed the positive impact of m-learning on students' academic performance with significant mediation of facilitation discourse. The effective utilization of mobile technology for successful learning, improvements in educational outputs and innovating teaching approaches in formal education are greatly influenced by instructor's role in enabling an active learning environment. Here, the teacher plays active role in supporting studentteacher and student-student interactions without impeding the essence of traditional classroom setting (Pedro et al., 2018). This unveiled an intervening role of facilitation discourse that develops when students undertake m-learning to improve their education outcomes. The results of the study are parallel with finding of Pedro et al. (2018). Intervention of wireless technology in academic surroundings promotes instructor's responsibility as "discussion facilitator" and "media orchestrator" to accomplish the fundamental objective of boosting students' understanding (Lepp, Barkley, \& Karpinski, 2015). Jenkins, Ito, and Boyd (2015) studied impact of teacher's stimulated active participatory discussion to deepen learning of students that takes place during usage of mobile technology. The result highlights the significant impact of m-learning on students' education performance mediate by supportive role of academicians. The similar outcomes are obtained from this study.

The mediating effect of facilitation discourse on the relationship between $\mathrm{m}$ learning and students' educational productivity was found significant. Similar impact was also established by Zhao and Frank (2003). They resolved that mobile learning culture within an institution, spontaneously empowers teachers to capitalize upon technology resource, improve their expertise, facilitate discourse and accomplish institutional goals which include academic uplift of the students. Using mobile technology for seeking education, places huge responsibility on the instructors who have to keenly focus on effectively designing and delivering blended (online) courses (Alammary, Sheard, \& Carbone, 2014). Faculty plays critical role in carrying out deliberate learning using media integrated mode of learning for accomplishing effective knowledge outcomes for the students (Holden \& Westfall, 2006). Thus, selection of media greatly affects the effectiveness of teachers' instruction and learning outcomes for the student (Holden \& Westfall, 2006). In order to obtain better outcomes, students and instructors must be equipped with logistical, didactic and technical assistance for assimilating mobile devices, applications for collective and online learning ( $\mathrm{Wu}, \mathrm{Hwang}, \mathrm{Su}$, \& Huang, 2012). With the advent of mobile technology, there has been a remarkable shift from outmoded channels of instruction such as class room lectures, where the student remains inactive recipient of the knowledge, towards a cooperative approach of learning where students are as active as teachers and both are entirely engaged in sharing ideas and 
information with each other (Falloon, 2013; Melhuish \& Falloon, 2010). M-learning urges institutions for its inception in teaching methodology and further pursue availability of trained teaching staff, multiplicity in instruction modes, instructor's accessibility to a number of learning opportunities, student-centered pedagogy, presence of optimized coworker learning and feedback (Arnold, 2011).

\subsection{M-learning for enhanced students' academic performance via flexibility}

The results revealed significant positive impact of m-learning on students' scholastic performance with significant mediation of flexibility. The results are corresponding with the previously conducted studies of Almasri (2018); Nie et al. (2011) and Shim and Shim (2001). Wave after wave of internet technology, m-learning is seemed crucial in Higher Education Institutions to promote interoperability, convenience and multi-dimensionality of academic assets that further endorse interaction and flexibility in learning mechanisms. This process further adds to encourage students in increasing their academic performance. The correlation value exhibit significant positive relationships among the underlying variables, which have already been qualitatively validated in previous studies by Crompton (2013) and Yousuf (2007). M-learning offers adaptability that is principally required for students to access learning material and professionals to obtain degrees through virtual education. This flexibility materialized as a result of mobile learning, helps students to access knowledge sources, lectures and learning material and actively engage in dialogue from anywhere at any time (Crompton, 2013). The outcome of SEM demonstrated appropriate model fit and displayed significant impacts on students' academic performance. Flexibility mediates the relationship between m-learning and educational outcomes of the learners. Henceforth, the findings strongly contribute to the existing literature.

Students receive greater extent of malleability when use wireless learning devices, which helps them to adjust schedule for study. From instructors' perspective, adaptability assists in innovating pedagogical techniques that are deeply absorbed by students and make them able to retain knowledge for longer time periods. Flexible learning provides opportunity to interact more, share feedback, and cooperate with peers and teachers (Carlson, 2000). Flexibility is highly valued by students, as access to content at any place and time enhances their readability and knowledge, which supports them to score well in assessments. Pre-loaded content is one of the major benefits of flexibility, due to which students seek uninterrupted information within and outside campus. The major purpose of e-learning has been to provide opportunity to students to grab learning through flexible means, but m-learning moved ahead to accomplish strategic objectives of improving the theoretical as well as practical learning and performance of the knowledge seekers through greater adaptability (Amaka \& Goeman, 2017). M-learning opens up ways for teachers and learners to earn opportunity of flexibility in accessing learning or course material at any convenient place and time (Fuegen, 2012). It facilitates in terms of both i.e., from perspective of pedagogy and scheduling according to one's ease. This flexibility, obtained as a result of using mobile technology, helps learners to develop competencies while gaining knowledge at their appropriate pace, thus leading to achieve maximum prospects in the future (Yousuf, 2007). Hence, it can be explicitly stated that mobile learning, being the major enabler of distance learning, provides most adaptive and accommodating form of knowledge seeking (Park, 2011). The adaptability gained through m-learning results in greater engagement, motivation and performance of the students (Kerawalla et al., 2007). It allows them to be more empowered in making choices and taking control of learning practices and approaches at personalized times. 
Flexible learning developed through mobile technology creates student-centered understanding opens up prospects for self-study to solve problems and think innovatively; provides access greater learners' population and delivers diversity of learning settings, experiences and scopes of study. Consequently, problem-based, digitized blended and experiential learnings support learners to perform exceptionally and accomplish their educational goals (Lim, 2004).

The results of current study are aligned with the outcomes of previous researched and the model formed it strong basis under the insights of Media Richness Theory. The results strongly support the notion that mobile technologies play critical role in elevating and enhancing students' learning and deepen communication among the interacting individuals (Sarrab, 2015).

\section{Conclusion}

Deeply analysing the trend of using mobile technology for virtual learning, it is quite evident that there is a continuous increasing tendency towards owning mobiles for flexible and participative knowledge acquisition. While appreciating the benefits of mobile-learning, the outcomes strongly emphasize role of course instructors in facilitating student learning and improving their learning effectiveness through variability in learning methods. Although, academia has secured huge benefits from electronic and mobile-based-learning, but still there is more space to actually realize the potential of mlearning. Education sector has prime strategic objective of striving to provide flexible, meantime and enduring learning to diverse set of learners including young learners and employed professional. Instructors' critical role in promoting communication, dialogue and constructive discussion is the key to strengthen students' academic scholarship and grades in course work. Mobile technology has brought ground breaking benefits to the education management sector. As evident from results, m-learning has created striking benefits for learners, enabling them to resolve issues of time and location for learning, accessing academic content and assignments using mobile devices. For instructors, the benefits include ease of uploading lessons on online portals, allocating tasks, stimulating discussions and collecting assignments through digitized media. Although, ubiquity is the major payback of m-leaning, which can only be realized and accomplished only if learning content is analytically planned and delivered to students. Resultantly, sustained learning takes place when appropriately formulated and implemented by the instructor.

Flexibility and Online Collaborative Learning (OCL) are the foundations of accomplishing students' learning objectives through mobile learning, thus leading to build resilient foundation of students' productivity in academics, pedagogy and philosophy (Sung et al., 2016). When HEIs incorporate teaching pedagogy and learning through mobile gadgets, consequently it become necessary for instructors to become active in smoothing and ensuring effective understanding of students with respect to learning content. The flexibility also come in to play to endorse and encourage mlearning for the beneficial prospects of students. M-learning brings multi-dimensionality to the entire learning process, as it deepens discussion and provide diverse paths to sustained learning. Learners conveniently adapt to different knowledge environments and enjoy benefits through learning in conceptual, social and physical spaces. Greater population of students is embracing m-learning due to the notion that cordless devices deliver more flexibility for accessing resources and study independently. Students prefer to use mobile gadgets for gaining education through m-learning from anywhere and at any time. This establishes sense of self-confidence among learners to value their knowledge and share their ideas with teachers and peers with firm belief. In m-learning, 
mobile device takes on role of service providers, that adds to build up maximum flexibility for the learners, subsequently, they stay update with the in-depths ideas and concepts, avail most of time for study and become highly motivated to learn. All these activities result in excellent performance of learners. Educationists, therefore, need to provide opportunity to learners to engage in m-learning for accomplishing their academic goals.

This has been accomplished that, students who use wireless technologies for learning mark better grades than those who learning through conventional learning method. This outcome of improved scholastic performance of students can be articulated in terms of high efficacy of note taking, higher retention of knowledge. Using mobiles and internet technology, learners personalize ways of receiving the required knowledge i.e. by means of text, video or audio. Higher Education Institutions in Pakistan are empowering students to use mobile gadgets in constructive manner while making sure provision of teachers' guidance when believed necessary. Universities have realized the significance of m-learning as it encourages students' interactivity and engagement in conventional or outdated didactic practice of teaching. Through m-learning, students are switching role from passive to active learners and have become more engaging and participatory from social, emotional and cognitive perspectives than ever before. This serves to play role of compelling technology supported learning that endorses learners' thoughts, actions and feeling, as result of which they become highly productive.

The findings also lead to conclude that m-learning necessitates instructors to stimulate situational discussion or discourse with and among the students so that they have in-depth understanding of the content within limited time. Teachers provide exhaustive orientation to students to comprehend the organization and scope of mlearning, thus consistently encourage them to remain strongly connected with their academic goals. Instructors' discourse makes m-learning effective for addressing the issues and subjects that students are keen and concerned about. Instructors engage students in innovative activities for enabling learning through mobile phones, which further allow maximum interaction and cooperation among peers and teachers. Students are able to improve their abilities of listening to audio lectures under the guidance of instructors. M-learning caters broader spectrum of learning especially for distant learners, in this regard teachers support them to get access to online learning forum and use it for discussion and dialogue. In order to obtain better outcomes, students and instructors must be equipped with logistical, didactic and technical assistance for assimilating mobile devices, applications for collective and online learning ( $\mathrm{Wu}$, Hwang, Su, \& Huang, 2012). M-learning undertakes to provide most suitable learning medium, but also creates a challenge for instructors to effectively use mobile technology to genuinely engage students and guide them successfully. Technology, as critical element in mobile learning or any virtual/distant education, creates essential need for teachers to enable maximum learning for students and remain consistent with learner-centered education (Anderson, 2008; Yousuf, 2007). Such academic practice ultimately leads to enhancement of scholars' academic performance.

A number of factors present favourable future avenues of using mobile learning especially in terms of innovation. In light of previous researches, the major revolutionary attributes of m-learning include delivering context specific knowledge, supplementing reality with virtual information, providing access to shared resources of knowledge acquisition, promoting dual flow of theoretical and practical insights from scholastic setting to industry and vice versa. The enthusiasm of students and learners of any academic level sustains its inspiration from HEIs to deliver online and shared learning through mobile technology. Thus, the study concludes that m-learning, supported through 
online instruction, can play an instrumental role in providing flexible and discussionoriented learning experience for teachers and students to perform outstanding in HEIs in Pakistan. It also highlights the simultaneous part of the teachers to effective guide their students to accomplish their educational missions.

\subsection{Recommendations}

Analysing the pros of digitized mobile-enabled teaching and learning and impact on students' performance is an ever-demanding domain of study and will remain emerging while the technology advancements continue to take place. Therefore, there is still needed to conduct academic investigations in this regard. HEIs need to transform frameworks that enable learners as well as teachers to assimilate mobile learning into the mechanism of sharing theoretical and practical knowledge between the knowledge delivering and seeking ends. There exist future possibilities for advanced analysis of the theme using quantitative techniques involving descriptive, correlational and multivariate statistical analysis. Future research studies can be accomplished through distinct approaches such as:

- Examining the impact of situational factors on efficacy of m-learning for effective student learning. The contingency factors can comprise of pedagogy, instructional resources, technology advancement, trainings of instructors etc.

- $\quad$ Empirically investigating and comparing the consequences of e-learning and digitized (online) mobile-learning on students' performance.

- Investigating the effectiveness of students' learning performance developed by using mobile assisted learning resources through secondary information source i.e. analysing their term grades.

- Quantitatively analysing the dynamics of m-learning and impact on learners' outcomes in local context and comparing the outcomes with global practices.

- Investigating the outcomes of m-learning for evaluating the competency development of professional learners and benefits gained by the institution.

\section{Acknowledgements}

This research has not been supported by any funding agency or commission. The authors would thank Prof. Dr. Ijaz A. Qureshi and Prof. Dr. Donna Schaeffer for their valuable guidance and support to this research.

\section{ORCID}

Aleema Shuja (iD https://orcid.org/0000-0003-2284-168X

Ijaz A. Qureshi (iD https://orcid.org/0000-0002-6956-052X

Donna M. Schaeffer (iD https://orcid.org/0000-0003-1972-4570

Memoona Zareen (D) https://orcid.org/0000-0003-1077-4993 


\section{References}

Ahmed, S., \& Parsons, D. (2013). Abductive science inquiry using mobile devices in the classroom. Computers \& Education, 63, 62-72.

Alalwan, N., Alzahrani, A., \& Sarrab, M. (2013). M-learning the next generation of education in cyberspace. World Academy of Science, Engineering and Technology (WASET), 75, 642-645.

Alammary, A., Sheard, J., \& Carbone, A. (2014). Blended learning in higher education: Three different design approaches. Australasian Journal of Educational Technology, 30(4), 440-454.

Al-Fahad, F. N. (2009). Students' attitudes and perceptions towards the effectiveness of mobile learning in King Saud University, Saudi Arabia. Turkish Online Journal of Educational Technology - TOJET, 8(2), 111-119.

AlHajri, R., Al-Sharhan, S., \& Al-Hunaiyyan, A. (2017). Students' perceptions of mobile learning: Case study of Kuwait. World Academy of Science, Engineering and Technology: International Journal of Educational and Pedagogical Sciences, 11(2), 371-374.

Alioon, Y., \& Delialioglu, O. (2015). A frame for the literature on m-learning. ProcediaSocial and Behavioral Sciences, 182, 127-135.

Almasri, A. K. M. (2018). New mobile learning process model for higher education students in Jordanian universities. International Journal of Information, Business and Management, 10(1), 201-213.

Almutairy, S. M., Davies, T., \& Dimitriadi, Y. (2015). The readiness of applying mlearning among Saudi Arabian students at higher education. International Journal of Interactive Mobile Technologies, 9(3), 33-36.

Aloraini, S. (2012). The impact of using multimedia on students' academic achievement in the college of education at King Saud University. Journal of King Saud UniversityLanguages and Translation, 24(2), 75-82.

Alqahtani, M., \& Mohammad, H. (2015). Mobile applications' impact on student performance and satisfaction. Turkish Online Journal of Educational TechnologyTOJET, 14(4), 102-112.

Alrasheedi, M., \& Capretz, L. F. (2015). An empirical study of critical success factors of mobile learning platform from the perspective of instructors. Procedia-Social and Behavioral Sciences, 176, 211-219.

Amaka, I. H., \& Goeman, K. (2017). Selecting media for effective learning in online and blended courses: A review study. Journal of Educational Multimedia and Hypermedia, 26(1), 29-59.

Anderson, T. (2004). Towards a theory of online learning. In T. Anderson (Ed.), Theory and Practice of Online Learning (Vol.2, pp. 109-119). Athabasca University Press.

Anderson, T. (Ed.). (2008). The theory and practice of online learning. Athabasca University Press.

Anderson, T., Liam, R., Garrison, D. R., \& Archer, W. (2001). Assessing teaching presence in a computer conferencing context. Journal of Asynchronous Learning Networks, 5(2), 1-17.

Andrews, T., Smyth, R., Tynan, B., Berriman, A., Vale, D., \& Caladine, R. (2011). Mobile technologies and rich media: Expanding tertiary education opportunities in developing countries. In A. G. Abdel-Wahab \& A. A. A. El-Masry (Eds.), Mobile Information Communication Technologies Adoption in Developing Countries: Effects and Implications (pp. 103-116). IGI Global.

Arnold, I. (2011). John Hattie: Visible learning: A synthesis of over 800 meta-analyses relating to achievement. Springer.

Arpaci, I. (2015). A comparative study of the effects of cultural differences on the 
adoption of mobile learning. British Journal of Educational Technology, 46(4), 699712.

Asiimwe, E. N., Grönlund, Å., \& Hatakka, M. (2017). Practices and challenges in an emerging m-learning environment. International Journal of Education and Development using Information and Communication Technology, 13(1), 103-122.

Bagozzi, R. P., Yi, Y., \& Phillips, L. W. (1991). Assessing construct validity in organizational research. Administrative Science Quarterly, 36(3), 421-458.

Balaji, M. S., \& Chakrabarti, D. (2010). Student interactions in online discussion forum: Empirical research from 'media richness theory' perspective. Journal of Interactive Online Learning, 9(1), 1-22.

Basri, W. S., Alandejani, J. A., \& Almadani, F. M. (2018). ICT adoption impact on students' academic performance: Evidence from Saudi Universities. Education Research International, 2018: 1240197.

Bentler, P. M., \& Bonett, D. G. (1980). Significance tests and goodness of fit in the analysis of covariance structures. Psychological Bulletin, 88(3), 588-606.

Bereiter, C., \& Scardamalia, M. (2014). Knowledge building and knowledge creation: One concept, two hills to climb. In S. C. Tan, H. J. So, \& J. Yeo (Eds.), Knowledge Creation in Education (pp. 35-52). Springer.

Bergamin, P. B., Ziska, S., Werlen, E., \& Siegenthaler, E. (2012). The relationship between flexible and self-regulated learning in open and distance universities. The International Review of Research in Open and Distributed Learning, 13(2), 101-123.

Butt, I. H., \& Qaisar, S. (2017). Readiness of Pakistani university teachers and students for m-learning in a public university. Journal of Research \& Reflections in Education (JRRE), 11(1), 86-96.

Carlson, S. (2000). Universities find wireless systems bring them convenience and savings. Chronicle of Higher Education, 47(7), A64-A64.

Chang, C. Y., \& Hwang, G. J. (2018). Trends in smartphone-supported medical education: A review of journal publications from 2007 to 2016. Knowledge Management \& ELearning, 10(4), 389-407.

Chiu, P. P., \& Li, R. K. (2015). Enhancing student motivation using LectureTools: A cloud-based teaching and learning platform. Knowledge Management \& E-Learning, $7(2), 250-264$.

Cho, Y. H., Lee, J., \& Jonassen, D. H. (2011). The role of tasks and epistemological beliefs in online peer questioning. Computers \& Education, 56(1), 112-126.

Cho, K., Lee, S., Joo, M. H., \& Becker, B. (2018). The effects of using mobile devices on student achievement in language learning: A meta-analysis. Education Sciences, 8(3): 105.

Clarke, B., \& James, C. (1998). Flexibility in post-registration nurse education in England. Innovations in Education and Training International, 35(4), 292-301.

Crompton, H. (2013). A historical overview of m-learning: Toward learner-centered education. In Z. L. Berge \& L. Y. Muilenburg (Eds.), Handbook of Mobile Learning (pp. 41-52). New York, NY: Routledge.

Daft, R. L., \& Lengel, R. H. (1986). Organizational information requirements, media richness and structural design. Management Science, 32(5), 554-571.

Dos, B. (2014). The relationship between mobile phone use, metacognitive awareness and academic achievement. European Journal of Educational Research, 3(4), 192200.

Doty, D. H., \& Glick, W. H. (1998). Common methods bias: Does common methods variance really bias results? Organizational Research Methods, 1(4), 374-406.

Driscoll, D. L. (2011). Introduction to primary research: Observations, surveys, and interviews. In C. Lowe \& P. Zemliansky (Eds.), Writing Spaces: Readings on Writing (Vol. 2, pp. 153-174). Anderson, SC: Parlor Press. 
Ebrahim, H. S., Ezzadeen, K., \& Alhazmi, A. K. (2015). Acquiring knowledge through mobile applications. International Journal of Interactive Mobile Technologies, 9(3), 71-74.

Elfeky, A. I. M., \& Masadeh, T. S. Y. (2016). The effect of mobile learning on students' achievement and conversational skills. International Journal of Higher Education, 5(3), 20-31.

El-Hussein, M. O. M., \& Cronje, J. C. (2010). Defining mobile learning in the higher education landscape. Educational Technology \& Society, 13(3), 12-21.

Emerson, L. C., \& Berge, Z. L. (2018). Microlearning: Knowledge management applications and competency-based training in the workplace. Knowledge Management \& E-Learning, 10(2), 125-132.

Faizi, R. (2018). Moroccan higher education students' and teachers' perceptions towards using Web 2.0 technologies in language learning and teaching. Knowledge Management \& E-Learning, 10(1), 86-96.

Fakomogbon, M. A., \& Bolaji, H. O. (2017). Effects of collaborative learning styles on performance of students in a ubiquitous collaborative mobile learning environment. Contemporary Educational Technology, 8(3), 268-279.

Falloon, G. (2013). Young students using iPads: App design and content influences on their learning pathways. Computers \& Education, 68, 505-521.

Hameed, F., \& Qayyum, A. (2018). Determinants of behavioral intention towards mobile learning in Pakistan: Mediating role of attitude. Business \& Economic Review, 10(1), 33-62.

Farid, S., Ahmad, R., Niaz, I. A., Arif, M., Shamshirband, S., \& Khattak, M. D. (2015). Identification and prioritization of critical issues for the promotion of e-learning in Pakistan. Computers in Human Behavior, 51(Part A), 161-171.

Field, A. (2013). Discovering statistics using IBM SPSS statistics. London, UK: Sage.

Fornell, C., \& Larcker, D. F. (1981). Evaluating structural equation models with unobservable variables and measurement error. Journal of Marketing Research, 18(1), 39-50.

Froese, A. D., Carpenter, C. N., Inman, D. A., Schooley, J. R., Barnes, R. B., Brecht, P. W., \& Chacon, J. D. (2012). Effects of classroom cell phone use on expected and actual learning. College Student Journal, 46(2), 323-332.

Frohberg, D., Göth, C., \& Schwabe, G. (2009). Mobile learning projects-A critical analysis of the state of the art. Journal of Computer Assisted Learning, 25(4), 307331.

Fu, Q. K. (2018). Impacts of mobile technologies, systems and resources on language learning: A systematic review of selected journal publications from 2007-2016. Knowledge Management \& E-Learning, 10(4), 375-388.

Fuegen, S. (2012). The impact of mobile technologies on distance education. Tech Trends, $56(6), 49-53$.

Gaskin, J. (2013). SEM series part 2: Data screening. Gaskination's Statistics.

Glenn, M. (2008). The future of higher education: How technology will shape learning. Austin, TX: New Media Consortium.

Georgieva, E. S., Smrikarov, A. S., \& Georgiev, T. S. (2011). Evaluation of mobile learning system. Procedia Computer Science, 3, 632-637.

Gordon, N. (2014). Flexible pedagogies: Technology-enhanced learning. From the report series Flexible Pedagogies: Preparing for the Future. The Higher Education Academy.

Gorham, R. (2010). Book Review: Mobile learning: Transforming the delivery of education and training. International Journal of E-Learning \& Distance Education, 24(3): 5 . 
Grenier, D. P. (2018). The relationship between mobile learning and academic achievement in a community college system online environment. Doctoral dissertation, Liberty University, USA.

Gupta, B., \& Koo, Y. (2012). Applications of mobile learning in higher education: An empirical study. In L. Tomei (Ed.), Advancing Education with Information Communication Technologies: Facilitating New Trends (pp. 268-281). IGI Global.

Guspatni, M. (2018). Students' activities in, perceptions of and expectations for elearning: A case in Indonesia. Knowledge Management \& E-Learning, 10(1), 97-112.

Hair, J. F., Sarstedt, M., Ringle, C. M., \& Mena, J. A. (2012). An assessment of the use of partial least squares structural equation modeling in marketing research. Journal of the Academy of Marketing Science, 40(3), 414-433.

Hamdan, K., \& Ben-Chaban, Y. (2013). An interactive mobile learning method to measure students performance. In Proceedings of the 12th World Conference on Mobile and Contextual Learning (mLearn 2013).

Hamm, S., Saltsman, G. J., Baldridge, S., \& Perkins, S. (2013). A mobile pedagogy approach for transforming learners and faculty. In Z. L. Berge \& L. Y. Muilenburg (Eds.), Handbook of Mobile Learning (pp. 176-186). New York, NY: Routledge.

Hernández, F. A. L., \& Pérez, M. M. S. (2014). M-learning patterns in the virtual classroom. International Journal of Educational Technology in Higher Education, $11(1), 208-221$.

Higgins, S., Xiao, Z., \& Katsipataki, M. (2012). The impact of digital technology on learning: A summary for the education endowment foundation. Durham, UK: Education Endowment Foundation and Durham University.

Holden, J. T., \& Westfall, P. J. L. (2006). An instructional media selection guide for distance learning. United States Distance Learning Association.

Huang, L. Y., \& Hsieh, Y. J. (2012). Consumer electronics acceptance based on innovation attributes and switching costs: The case of e-book readers. Electronic Commerce Research and Applications, 11(3), 218-228.

Huang, Y. M., Lin, Y. T., \& Cheng, S. C. (2010). Effectiveness of a mobile plant learning system in a science curriculum in Taiwanese elementary education. Computers \& Education, 54(1), 47-58.

Huet, J. M., \& Tcheng, H. (2010). What if telecoms-were the key to the third industrial revolution? Paris: Pearson Education France.

Idir, R., \& Iskounen, S. (2018). Investigating the impact of using mobile technology on improving EFL students' learning achievement: A case study. Master dissertation, Université de Bejaia, Algeria.

Ifeanyi, I. P., \& Chukwuere, J. E. (2018). The impact of using smartphones on the academic performance of undergraduate students. Knowledge Management \& ELearning, 10(3), 290-308.

Isbell, D. R., Rawal, H., Oh, R., \& Loewen, S. (2017). Narrative perspectives on selfdirected foreign language learning in a computer-and mobile-assisted language learning context. Languages, 2(2): 4.

Ismail, I., Gunasegaran, T., Koh, P. P., \& Idrus, R. M. (2010). Satisfaction of distance learners towards mobile learning in the Universiti Sains Malaysia. Malaysian Journal of Educational Technology, 10(2), 47-54.

Ismail, A. O., Mahmood, A. K., \& Abdelmaboud, A. (2018). Factors influencing academic performance of students in blended and traditional domains. International Journal of Emerging Technologies in Learning (iJET), 13(2), 170-187.

Jacob, S. M., \& Issac, B. (2014). Mobile learning culture and effects in higher education. arXiv preprint arXiv:1410.4379.

Jacobs, I. (2013). Modernizing education and preparing tomorrow's workforce through mobile technology. Paper presented at the i4j Summit. 
Jakobsen, M., \& Jensen, R. (2015). Common method bias in public management studies. International Public Management Journal, 18(1), 3-30.

Jenkins, H., Ito, M., \& Boyd, D. (2015). Participatory culture in a networked era: A conversation on youth, learning, commerce, and politics. Cambridge, UK: Polity Press..

Jin, X., Zhang, X., \& Luo, H. (2017). Effects of mobile learning on academic performance and learning attitude in a college classroom. In Proceedings of the 4th International Conference on Advanced Education and Management (ICAEM 2017) (pp. 307-311).

Joyce, T. B. Y., \& Yates, S. M. (2007). A rasch analysis of the academic self-concept questionnaire. International Education Journal, 8(2), 470-484.

Kamarainen, A. M., Metcalf, S., Grotzer, T., Browne, A., Mazzuca, D., Tutwiler, M. S., $\&$ Dede, C. (2013). EcoMOBILE: Integrating augmented reality and probeware with environmental education field trips. Computers \& Education, 68, 545-556.

Kanwal, M. (2017). Pakistan will have 17 million new mobile subscribers by 2020, GSMA report. TECHJUICE. Retrieved from https://www.techjuice.pk/gsma-mobileeconomy-2017-report-pakistan-mobile/

Karacapilidis, N., \& Papadias, D. (2001). Computer supported argument and collaborative decision making: The HERMES system. Information System, 26(4), 259-277.

Kasantra, T., Ho, S. C., Tan, L. K., Tan, S. Y., \& Tan, W. M. (2013). Analysis of factors influencing the academic performance of undergraduates in Kampar. Retrieved from http://eprints.utar.edu.my/1016/1/AC-2013-0904962-1.pdf

Kent, M. (2016). Adding to the mix: Students use of Facebook groups and blackboard discussion forums in higher education. Knowledge Management \& E-Learning, 8(3), 444-463.

Kerawalla, L., O'Connor, J., Underwood, J., duBoulay, B., Holmberg, J., Luckin, R., ... Tunley, H. (2007). Exploring the potential of the homework system and tablet PCs to support continuity of numeracy practices between home and primary school. Educational Media International, 44(4), 289-303.

Keskin, N. O., \& Metcalf, D. (2011). The current perspectives, theories and practices of mobile learning. TOJET: The Turkish Online Journal of Educational Technology, 10(2), 202-208.

Khan, A. A., Siddiqui, A. Z., Mohsin, S. F., Al Momani, M. M., \& Mirza, E. H. (2017). Impact of network aided platforms as educational tools on academic performance and attitude of pharmacology students. Pakistan Journal of Medical Sciences, 33(6), 1473-1478.

Kiemer, K., Gröschner, A., Pehmer, A. K., \& Seidel, T. (2015). Effects of a classroom discourse intervention on teachers' practice and students' motivation to learn mathematics and science. Learning and Instruction, 35, 94-103.

Koehler, M. J., Mishra, P., \& Cain, W. (2013). What is technological pedagogical content knowledge (TPACK)? Journal of Education, 193(3), 13-19.

Korucu, A. T., \& Alkan, A. (2011). Differences between m-learning (mobile learning) and e-learning, basic terminology and usage of m-learning in education. ProcediaSocial and Behavioral Sciences, 15, 1925-1930.

Kres, H. (2012). Statistical tables for multivariate analysis: A handbook with references to applications. New York, NY: Springer-Verlag.

Kromhout, P. J. (2011). The effect of media usage, trust, and relations on the productivity, innovativeness and flexibility of teleworkers, and how knowledge sharing and telework frequency influences these relationships. Erasmus Universiteit.

Kumar Jena, A., \& Pokhrel, K. (2017). Effects of collaborative m-learning and individual 
e-learning on the academic performance, attention benefit and consistency of learning. The Online Journal of Distance Education and E-Learning, 5(1), 35-46.

Kupczynski, L., Ice, P., Wiesenmayer, R., \& McCluskey, F. (2010). Student perceptions of the relationship between indicators of teaching presence and success in online courses. Journal of Interactive Online Learning, 9(1), 23-43.

Lai, H. C., Chang, C. Y., Li, W. S., Fan, Y. L., \& Wu, Y. T. (2013). The implementation of mobile learning in outdoor education: application of QR codes. British Journal of Educational Technology, 44(2), E57-E62.

Lan, Y. F., \& Sie, Y. S. (2010). Using RSS to support mobile learning based on media richness theory. Computers \& Education, 55(2), 723-732.

Laves, E. (2010). The impact of teaching presence in intensive online courses on perceived learning and sense of community: A mixed methods study. Doctoral dissertation, University of Nebraska - Lincoln, USA.

Lepp, A., Barkley, J. E., \& Karpinski, A. C. (2015). The relationship between cell phone use and academic performance in a sample of US college students. Sage Open, 5(1). doi: $10.1177 / 2158244015573169$

Leko, M. M., Kiely, M. T., Brownell, M. T., Osipova, A., Dingle, M. P., \& Mundy, C. A. (2015). Understanding special educators' learning opportunities in collaborative groups: The role of discourse. Teacher Education and Special Education, 38(2), 138157.

Lewin, T., \& Mawoyo, M. (2014). Student access and success: Issues and interventions in South African universities. Inyathelo: The South African Institute for Advancement.

Li, K. C. (2018). The evolution of open learning: A review of the transition from pre-elearning to the era of e-learning. Knowledge Management \& E-Learning, 10(4), 408425.

Li, K. C., Lee, L. Y. K., Wong, S. L., Yau, I. S. Y., \& Wong, B. T. M. (2017). Mobile learning in nursing education: Catering for students and teachers' needs. Asian Association of Open Universities Journal, 12(2), 171-183.

Lim, D. H. (2004). The effect of flexible learning schedule on online learners' learning, application, and instructional perception. In Proceedings of the Academy of Human Resource Development International Conference: Symposium 49-1 (pp. 1060-1066).

Liu, T. C., Wang, H. Y., Liang, J. K., Chan, T. W., Ko, H. W., \& Yang, J. C. (2003). Wireless and mobile technologies to enhance teaching and learning. Journal of Computer Assisted Learning, 19(3), 371-382.

Liu, Y., Li, H., \& Carlsson, C. (2010). Factors driving the adoption of m-learning: An empirical study. Computers \& Education, 55(3), 1211-1219.

Little, B. (2012). Effective and efficient mobile learning: issues and tips for developers. Industrial and Commercial Training, 44(7), 402-407.

Lowenthal, P. R. (2016). A mixed methods examination of instructor social presence in accelerated online courses. In L. Kyei-Blankson, J. Blankson, E. Ntuli, \& C. Agyeman (Eds.), Handbook of Research on Strategic Management of Interaction, Presence, and Participation in Online Courses (pp. 147-159). IGI Global.

Lu, M. (2008). Effectiveness of vocabulary learning via mobile phone. Journal of computer assist learning, 24(6), 515-525.

MacCallum, K., \& Jeffrey, L. (2009). Identifying discriminating variables that determine mobile learning adoption by educators: An initial study. In Proceedings of ascilite: Same places, different spaces. Auckland.

Males, S., Bate, F., \& Macnish, J. (2017). The impact of mobile learning on student performance as gauged by standardised test (NAPLAN) scores. Issues in Educational Research, 27(1), 99-114.

Martha, K. (2009). Factors affecting academic performance of undergraduate students at Uganda Christian University. Master of Arts in Educational Management dissertation, 
Makerere University, Uganda.

Maulana, R., Opdenakker, M. C., \& Bosker, R. (2016). Teachers' instructional behaviors as important predictors of academic motivation: Changes and links across the school year. Learning and Individual Differences, 50, 147-156.

Mayer, R. E., \& Clark, R. C. (2011). E-learning and the science of instruction: Proven guidelines for consumers and designers of multimedia learning. San Francisco, CA: Pfeiffer.

Mazzolini, M., \& Maddison, S. (2007). When to jump in: The role of the instructor in online discussion forums. Computers \& Education, 49(2), 193-213.

Means, B., Toyama, Y., Murphy, R., Bakia, M., \& Jones, K. (2009). Evaluation of evidence-based practices in online learning: A meta-analysis and review of online learning studies. Washington, DC: US Department of Education.

Menchaca, M. P., \& Bekele, T. A. (2008). Learner and instructor identified success factors in distance education. Distance Education, 29(3), 231-252.

Melhuish, K., \& Falloon, G. (2010). Looking to the future: M-learning with the iPad. Computers in New Zealand Schools, 22(3), 1-16.

Miller, H. B., \& Cuevas, A. J. (2017). Mobile learning and its effects on academic achievement and student motivation in middle grades students. International Journal for the Scholarship of Technology Enhanced Learning, 1(2), 91-110.

Moore, J. L., Dickson-Deane, C., \& Galyen, K. (2011). e-Learning, online learning, and distance learning environments: Are they the same? The Internet and Higher Education, 14(2), 129-135.

Moseki, M., \& Schulze, S. (2010). Promoting self-regulated learning to improve achievement: A case study in higher education. Africa Education Review, 7(2), 356375.

Navaridas, F., Santiago, R., \& Tourón, J. (2013). Opinions from teachers in the Fresno area of Central California regarding the influence of mobile technology on their students' learning. RELIEVE, 19(2): 4.

Nestel, D., Gray, K., Ng, A., McGrail, M., Kotsanas, G., \& Villanueva, E. (2014). Mobile learning in a rural medical school: Feasibility and educational benefits in campus and clinical settings. Journal of Biomedical Education, 2014: 412786.

$\mathrm{Ng}$, W., \& Nicholas, H. (2013). A framework for sustainable mobile learning in schools. British Journal of Educational Technology, 44(5), 695-715.

Niculescu, I., Rees, R., \& Gash, D. (2017). An exploration into pedagogic frailty: Transitioning from face-to-face to online. Knowledge Management \& E-Learning, 9(3), 392-403.

Nie, M., Armellini, A., Witthaus, G., \& Barklamb, K. (2011). How do e-book readers enhance learning opportunities for distance work-based learners? Research in Learning Technology, 19(1), 19-38.

Okeleke, K., Rogers, M., \& Pedros, X. (2017). The mobile economy 2017. GSMA Intelligence. Retrieved from https://www.gsmaintelligence.com/research/?file=9e927fd6896724e7b26f33f61db5b9 d5\&download

Olasina, G. (2018). Factors of best practices of e-learning among undergraduate students. Knowledge Management \& E-Learning, 10(3), 265-289.

O'Malley, C., Vavoula, G., Glew, J. P., Taylor, J., Sharples, M., Lefrere, P., \& Waycott, J. (2005). Guidelines for learning/teaching/tutoring in a mobile environment. Retrieved from https://hal.archives-ouvertes.fr/hal-00696244/

Osborne, J. F., Borko, H., Fishman, E., Gomez Zaccarelli, F., Berson, E., Busch, K. C., \& Tseng, A. (2019). Impacts of a practice-based professional development program on elementary teachers' facilitation of and student engagement with scientific 
argumentation. American Educational Research Journal. doi: $10.3102 / 0002831218812059$

Owino, O. (2013). The impact of e-learning on academic performance: A case study of group learning sets. Unpublished Masters Project. University of Nairobi.

Ozdamli, F., \& Uzunboylu, H. (2015). M-learning adequacy and perceptions of students and teachers in secondary schools. British Journal of Educational Technology, 46(1), $159-172$.

Pakistan Telecommunication Authority (PTA). (2017). Telecome indicators. Retrieved form

http://www.pta.gov.pk/index.php?option=com_content\&task=view\&id=269\&Itemid= $\underline{658}$

Pallant, J. (2013). SPSS survival manual. Maidenhead, Berkshire, UK: McGraw-Hill Education.

Palmer, S. R. (2011). The lived experience of flexible education--Theory, policy and practice. Journal of University Teaching \& Learning Practice, 8(3), 1-16.

Panjaburee, P., \& Srisawasdi, N. (2018). The opportunities and challenges of mobile and ubiquitous learning for future schools: A context of Thailand. Knowledge Management \& E-Learning, 10(4), 485-506.

Park, Y. (2011). A pedagogical framework for mobile learning: Categorizing educational applications of mobile technologies into four types. The International Review of Research in Open and Distributed Learning, 12(2), 78-102.

Pedro, L. F. M. G., de Oliveira Barbosa, C. M. M., \& das Neves Santos, C. M. (2018). A critical review of mobile learning integration in formal educational contexts. International Journal of Educational Technology in Higher Education, 15: 10.

Penwarden, R., (2013). Tips for overcoming researcher bias. FluidSurveys University. Retrieved from http://fluidsurveys.com/university/tips-for-overcoming-researcherbias/

Perry, E. H., \& Pilati, M. L. (2011). Online learning. New Directions for Teaching and Learning, 128, 95-104.

Pimmer, C., Mateescu, M., \& Gröhbiel, U. (2016). Mobile and ubiquitous learning in higher education settings. A systematic review of empirical studies. Computers in Human Behavior, 63, 490-501.

Plass, J. L., Moreno, R., \& Brünken, R. (2010). Cognitive load theory. Cambridge University Press.

Potter, J. (2013). Beyond access: Student perspectives on support service needs in distance learning. Canadian Journal of University Continuing Education, 24(1), 5982.

Qureshi, I. A., Ilyas, K., Yasmin, R., \& Whitty, M. (2012). Challenges of implementing e-learning in a Pakistani university. Knowledge Management \& E-Learning, 4(3), $310-324$.

Rabiu, H., Muhammed, A. I., Umaru, Y., \& Ahmed, H. T. (2016). Impact of mobile phone usage on academic performance among secondary school students in Taraba State, Nigeria. European Scientific Journal, 12(1), 466-479.

Rambe, P., \& Bere, A. (2013). Using mobile instant messaging to leverage learner participation and transform pedagogy at a South African University of Technology. British Journal of Educational Technology, 44(4), 544-561.

Rashid, T., \& Asghar, H. M. (2016). Technology use, self-directed learning, student engagement and academic performance: Examining the interrelations. Computers in Human Behavior, 63, 604-612.

Ratto, M., Shapiro, R. B., Truong, T. M., \& Griswold, W. G. (2003). The activeclass project: Experiments in encouraging classroom participation. In B. Wasson, S. Ludvigsen, \& U. Hoppe (Eds.), Designing for Change in Networked Learning 
Environments (pp. 477-486). Springer.

Raykov, T. (2011). Evaluation of convergent and discriminant validity with multitraitmultimethod correlations. British Journal of Mathematical and Statistical Psychology, 64(1), 38-52.

Reinders, H., \& Benson, P. (2017). Research agenda: Language learning beyond the classroom. Language Teaching, 50(4), 561-578.

Richardson, H. A., Simmering, M. J., \& Sturman, M. C. (2009). A tale of three perspectives: Examining post hoc statistical techniques for detection and correction of common method variance. Organizational Research Methods, 12(4), 762-800.

Rockley, A., \& Cooper, C. (2012). Managing enterprise content: A unified content strategy. Berkeley, CA: New Riders.

Roschelle, J., Rafanan, K., Bhanot, R., Estrella, G., Penuel, B., Nussbaum, M., \& Claro, S. (2010). Scaffolding group explanation and feedback with handheld technology: Impact on students' mathematics learning. Educational Technology Research and Development, 58(4), 399-419.

Rudd II, D. P., \& Rudd, D. P. (2014). The value of video in online instruction. Journal of Instructional Pedagogies, $13 . \quad$ Retrieved from https://files.eric.ed.gov/fulltext/EJ1060143.pdf

Ryan, A., \& Tilbury, D. (2013). Flexible pedagogies: New pedagogical ideas. London, UK: Higher Education Academy.

Saccol, A. Z., Reinhard, N., Schlemmer, E., \& Barbosa, J. L. (2010). M-learning (mobile learning) in practice: A training experience with it professionals. JISTEM-Journal of Information Systems and Technology Management, 7(2), 261-280.

Sahu, P. K., Pal, S. R., \& Das, A. K. (2015). Estimation and inferential statistics. Springer.

Salinda Premadasa, H. K., \& Gayan N. Meegama, R. (2013). Mobile learning environment with short messaging service: Application to a campus environment in a developing country. Campus-Wide Information Systems, 30(2), 106-123.

Sampson, D. G., \& Zervas, P. (2013). Learning object repositories as knowledge management systems. Knowledge Management \& E-Learning, 5(2), 117-136.

Sarrab, M. (2015). M-learning in education: Omani undergraduate students' perspective. Procedia-Social and Behavioral Sciences, 176, 834-839.

Schreiber, J. B., Nora, A., Stage, F. K., Barlow, E. A., \& King, J. (2006). Reporting structural equation modeling and confirmatory factor analysis results: A review. The Journal of Educational Research, 99(6), 323-338.

Selwyn, N. (2010). Looking beyond learning: Notes towards the critical study of educational technology. Journal of Computer Assisted Learning, 26(1), 65-73.

Sha, L., Looi, C. K., \& Chen, W. (2012). Moura, A., \& Carvalho, A. A. (2008). Mobile learning: Teaching and learning with mobile phones and podcasts. In Proceedings of the Eighth IEEE International Conference on Advanced Learning Technologies.

Shackelford, J. L., \& Maxwell, M. (2012). Sense of community in graduate online education: Contribution of learner to learner interaction. The International Review of Research in Open and Distributed Learning, 13(4), 228-249.

Shaffer, D. W. (2006). How computer games help children learn. New York, NY: Macmillan.

Shea, P., Li, C. S., Swan, K., \& Pickett, A. (2005). Developing learning community in online asynchronous college courses: The role of teaching presence. Journal of Asynchronous Learning Networks, 9(4), 59-82.

Shim, M. K., \& Shim, S. J. (2001). Mobile computing in higher education: Faculty perceptions of benefits and barriers. Journal of Educational Technology Systems, 29(4), 345-354. 
Shimada, S. (2017). An effective method of collecting practical knowledge by presentation of videos and related words. Knowledge Management \& E-Learning, 9(4), 468-483.

Shonola, S. A., Joy, M. S., Oyelere, S. S., \& Suhonen, J. (2016). The impact of mobile devices for learning in higher education institutions: Nigerian universities case study. International Journal of Modern Education and Computer Science, 8, 43-50.

Stark, E., Lassiter, A. L., \& Kuemper, A. (2013). A brief examination of predictors of elearning success for novice and expert learners. Knowledge Management \& ELearning, 5(3), 269-277.

Straub, E. T. (2009). Understanding technology adoption: Theory and future directions for informal learning. Review of Educational Research, 79(2), 625-649.

Sulaiman, A., \& Dashti, A. (2018). Students' satisfaction and factors in using mobile learning among college students in Kuwait. EURASIA Journal of Mathematics, Science and Technology Education, 14(7), 3181-3189.

Sung, E., \& Mayer, R. E. (2013). Online multimedia learning with mobile devices and desktop computers: An experimental test of Clark's methods-not-media hypothesis. Computers in Human Behavior, 29(3), 639-647.

Sung, Y. T., Chang, K. E., \& Liu, T. C. (2016). The effects of integrating mobile devices with teaching and learning on students' learning performance: A meta-analysis and research synthesis. Computers \& Education, 94, 252-275.

Sung, Y. T., Yang, J. M., \& Lee, H. Y. (2017). The effects of mobile-computer-supported collaborative learning: Meta-analysis and critical synthesis. Review of Educational Research, 87(4), 768-805.

Swan, K., \& Shea, P. (2005). The development of virtual learning communities. In S. Hiltz \& R. Goldman (Eds.), Learning together Online: Research on Asynchronous Learning Networks (pp. 239-260). Mahwah, NJ: Lawrence Erlbaum.

Tabachnick, B. G., \& Fidell, L. S. (2007). Using multivariate statistics. Allyn \& Bacon/Pearson Education.

Tai, Y., \& Ting, Y. L. (2011). Adoption of mobile technology for language learning: Teacher attitudes and challenges. The JALT CALL Journal, 7(1), 3-18.

Taylor, R. (1990). Interpretation of the correlation coefficient: A basic review. Journal of Diagnostic Medical Sonography, 6(1), 35-39.

Tehseen, S., Ramayah, T., \& Sajilan, S. (2017). Testing and controlling for common method variance: A review of available methods. Journal of Management Sciences, $4(2), 146-175$.

Thomas, K., \& Orthober, C. (2011). Using text-messaging in the secondary classroom. American Secondary Education, 39(2),55-76.

Tinto, V. (1987). Leaving college: Rethinking the causes and cures of student attrition. Chicago, IL: University of Chicago Press.

Topchyan, R. (2016). Does social presence relate to knowledge sharing in virtual learning teams? Knowledge Management \& E-Learning, 8(4), 646-660.

Traxler, J. (2013). Mobile learning: Shaping the frontiers of learning technologies in global context. In R. Huang, Kinshuk, \& J. M. Spector (Eds.), Reshaping Learning (pp. 237-251). Springer.

Trifonova, A., \& Ronchetti, M. (2006, July). Mobile learning: Is anytime+ anywhere= always online? In Proceedings of the Sixth IEEE International Conference on Advanced Learning Technologies (pp. 702-706).

Trochim, W. M., (2008). Sampling terminology. Research Methods Knowledge Base. Retrieved from http://www.socialresearchmethods.net/kb/sampterm.php

Twum, R. (2014). Influence of mobile phone technologies on science students' academic performance in selected Ghanaian public universities. Doctoral dissertation, School of Education, Kenyatta University, USA. 
Valk, J. H., Rashid, A. T., \& Elder, L. (2010). Using mobile phones to improve educational outcomes: An analysis of evidence from Asia. The International Review of Research in Open and Distributed Learning, 11(1), 117-140.

Vural, O. F. (2013). The impact of a question-embedded video-based learning tool on elearning. Educational Sciences: Theory and Practice, 13(2), 1315-1323.

Vyas, N., \& Nirban, V. S. (2014). Students' perception on the effectiveness of mobile learning in an institutional context. ELT Research Journal, 3(1), 26-36.

Wai, I. S. H., Ng, S. S. Y., Chiu, D. K., Ho, K. K., \& Lo, P. (2018). Exploring undergraduate students' usage pattern of mobile apps for education. Journal of Librarianship and Information Science, 50(1), 34-47.

Wang, M., Shen, R., Novak, D., \& Pan, X. (2009). The impact of mobile learning on students' learning behaviors and performance: Report from a large blended classroom. British Journal of Educational Technology, 40(4), 673-695.

Waqar, Y. (2014). Towards a model of m-learning in Pakistan. Journal of Research and Reflections in Education, 8(2), 125-131.

Warschauer, M., Zheng, B., Niiya, M., Cotten, S., \& Farkas, G. (2014). Balancing the one-to-one equation: Equity and access in three laptop programs. Equity \& Excellence in Education, 47(1), 46-62.

Weichhart, G., Stary, C., \& Appel, M. (2018). The digital Dalton Plan: Progressive education as integral part of web-based learning environments. Knowledge Management \& E-Learning, 10(1), 25-52.

Wen, L., Brayshaw, M., \& Gordon, N. (2012). Personalized content provision for virtual learning environments via the semantic web. Innovation in Teaching and Learning in Information and Computer Sciences, 11(1), 14-26.

West, D. M. (2012). Digital schools: How technology can transform education. Washington, DC: Brookings Institution Press.

West, D. M. (2013). Mobile learning: Transforming education, engaging students, and improving outcomes. Washington, DC: Center for Technology Innovation at Brookings.

Wilen-Daugenti, T. (2009). Edu: Technology and learning environments in higher education. New York, NY: Peter Lang.

Wilkinson, K., \& Barter, P. (2016). Do mobile learning devices enhance learning in higher education anatomy classrooms? Journal of Pedagogic Development, 6(1), 1423.

Wong, G. K. W. (2014). Engaging students using their own mobile devices for learning mathematics in classroom discourse: A case study in Hong Kong. International Journal of Mobile Learning and Organisation, 8(2), 143-165.

Wong, K., Wang, F. L., Ng, K. K., \& Kwan, R. (2015). Investigating acceptance towards mobile learning in higher education students. In K. C. Li, T.-L. Wong, S. K. S. Cheung, J. Lam, \& K. K. Ng (Eds.), Technology in Education. Transforming Educational Practices with Technology (pp. 9-19). Springer.

Wu, P. H., Hwang, G. J., Su, L. H., \& Huang, Y. M. (2012). A context-aware mobile learning system for supporting cognitive apprenticeships in nursing skills training. Educational Technology \& Society, 15(1), 223-236.

Yang, K. T., Wang, T. H., \& Chiu, M. H. (2014). How technology fosters learning: Inspiration from the "Media Debate". Creative Education, 5, 1086-1090.

Yousuf, M. I. (2007). Effectiveness of mobile learning in distance education. Turkish Online Journal of Distance Education, 8(4), 114-124.

Yuan, B., Wang, M., Kushniruk, A. W., \& Peng, J. (2016). Design of a computer-based learning environment to support diagnostic problem solving towards expertise development. Knowledge Management \& E-Learning, 8(4), 540-549. 
Yüksel, A. (2017). A critique of "Response Bias" in the tourism, travel and hospitality research. Tourism Management, 59, 376-384.

Zare, M., Sarikhani, R., Salari, M., \& Mansouri, V. (2016). The impact of e-learning on university students' academic achievement and creativity. Journal of Technical Education and Training, 8(1), 25-33.

Zare Bidaki, M., Naderi, F., \& Ayati, M. (2013). Effects of mobile learning on paramedical students' academic achievement and self-regulation. Future of Medical Education Journal, 3(3), 24-28.

Zeb, Y. (2017). $3 G$ and $4 G$ users in Pakistan crossed 42 million in 2017-PTA. Retrieved from https://www.researchsnipers.com/3g-4g-users-pakistan-crossed-42-million2017-pta/

Zhao, Y., \& Frank, K. A. (2003). Factors affecting technology uses in schools: An ecological perspective. American Educational Research Journal, 40(4), 807-840.

Zou, D., Xie, H., \& Wang, F. L. (2018). Future trends and research issues of technologyenhanced language learning: A technological perspective. Knowledge Management \& E-Learning, 10(4), 426-440. 